Prepared in cooperation with the Bureau de Recherches Géologiques et Minières and the Direction Générale des Mines under the auspices of the U.S. Department of State

\title{
Alluvial Diamond Resource Potential and Production Capacity Assessment of the Central African Republic
}

Scientific Investigations Report $2010-5043$ 
Cover. Artisanal diamond mining of upper terrace deposits along the Kotto River near Oro, Central African Republic, May 2007. 


\section{Alluvial Diamond Resource Potential and Production Capacity Assessment of the Central African Republic}

By Peter G. Chirico, Francis Barthélémy, and François A. Ngbokoto

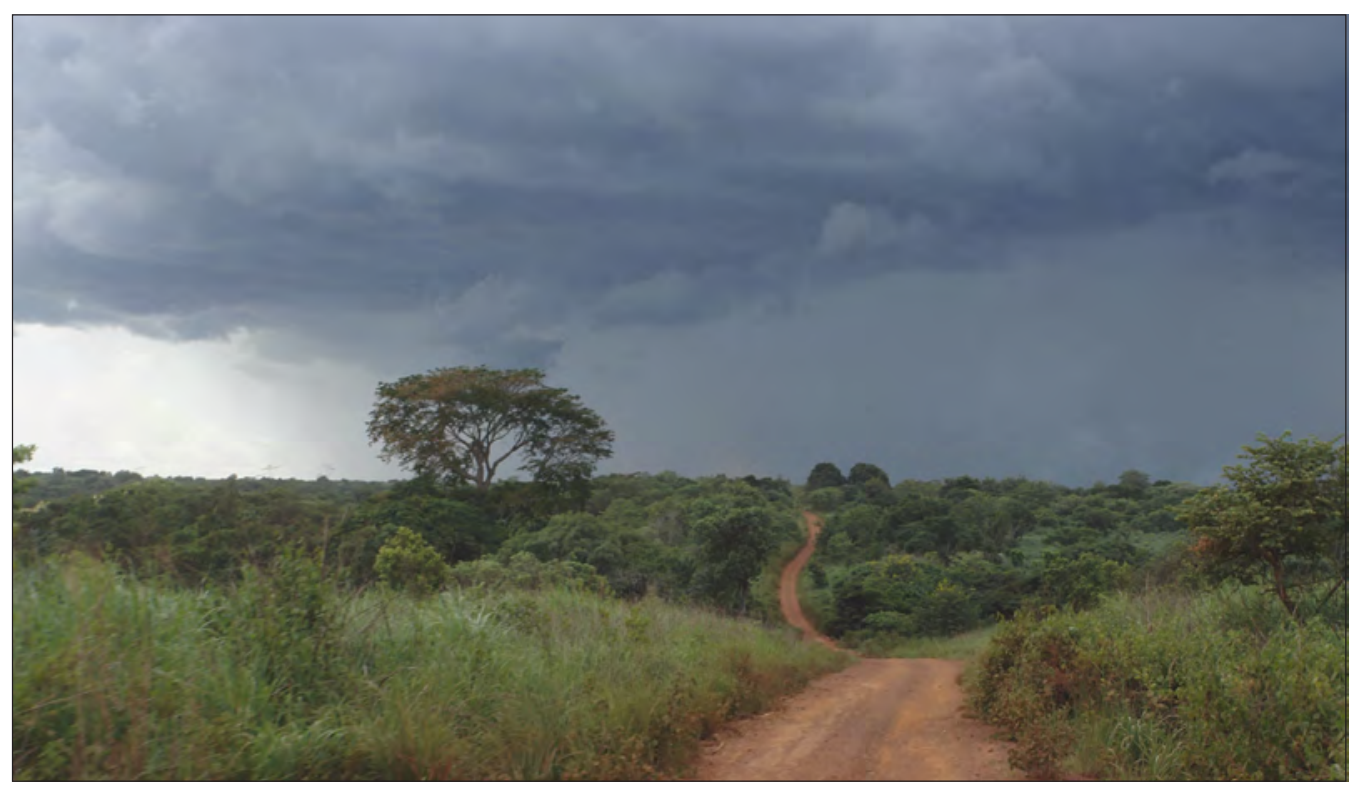

Road from Dimbi to Sibut, May 2007

Prepared in cooperation with the Bureau de Recherches Géologiques et Minières and the Direction Générale des Mines under the auspices of the U.S. Department of State

Scientific Investigations Report 2010-5043 


\title{
U.S. Department of the Interior \\ KEN SALAZAR, Secretary \\ U.S. Geological Survey \\ Marcia K. McNutt, Director
}

\section{U.S. Geological Survey, Reston, Virginia: 2010}

\author{
For more information on the USGS — the Federal source for science about the Earth, its natural and living resources, \\ natural hazards, and the environment, visit http://Www.usgs.gov or call 1-888-ASK-USGS \\ For an overview of USGS information products, including maps, imagery, and publications, \\ visit http://www.usgs.gov/pubprod \\ To order this and other USGS information products, visit http://store.usgs.gov
}

Any use of trade, product, or firm names is for descriptive purposes only and does not imply endorsement by the U.S. Government.

Although this report is in the public domain, permission must be secured from the individual copyright owners to reproduce any copyrighted materials contained within this report.

Suggested citation:

Chirico, P.G., Barthélémy, Francis, and Ngbokoto, F.A., 2010, Alluvial diamond resource potential and production capacity assessment of the Central African Republic: U.S. Geological Survey Scientific Investigations Report 2010-5043, 22 p.

(available only online at $h$ ttp://pubs.usgs.gov/sir/2010/5043/ 


\section{Contents}

Abstract

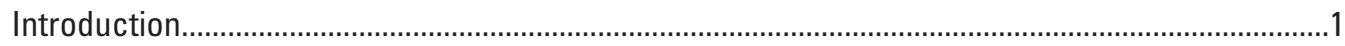

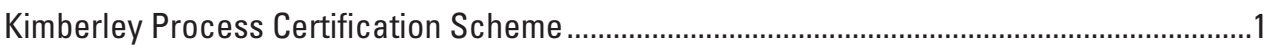

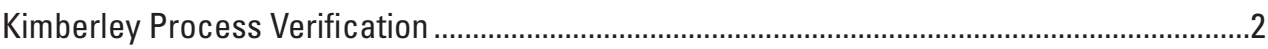

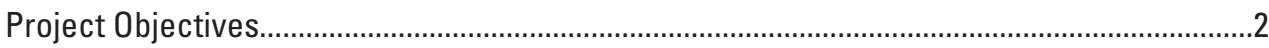

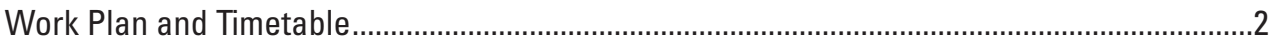

Phase 1: Research .....................................................................................................

Phase 2: Field Evaluation ..............................................................................................

Phase 3: Report Preparation .............................................................................................

Phase 4: Project Finalization ...........................................................................................

Team Organization ..............................................................................................................

Geologic Description of the Central African Republic with a Focus on Diamond Areas ..................3

Introduction to the Geology of the Central African Republic ..................................................

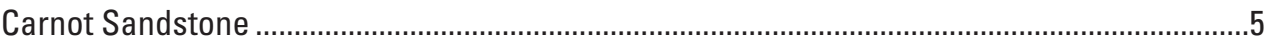

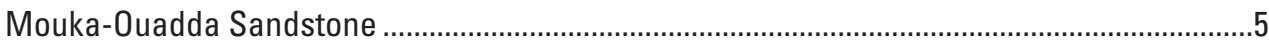

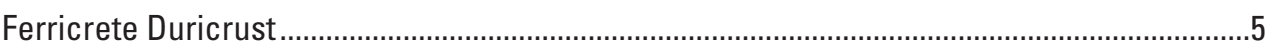

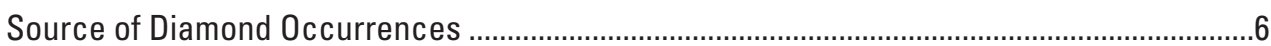

Alluvial Diamond Deposits........................................................................................................

History of Diamond Mining and Production ..................................................................................

Methodology for Assessing the Central African Republic Diamond Resource Potential .................9

Field Data Collection and Basic Research .........................................................................9

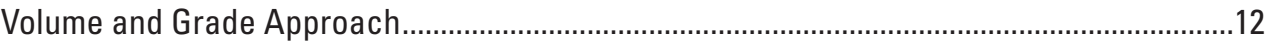

Content per Kilometer Approach .......................................................................................13

Methodology to Estimate the Capacity of the Central African Republic Diamond Production ......13

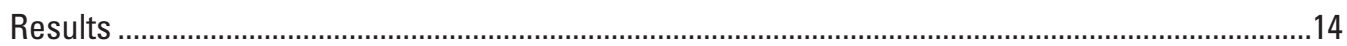

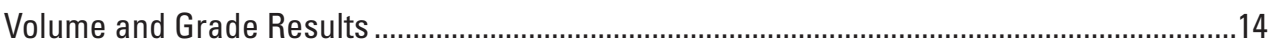

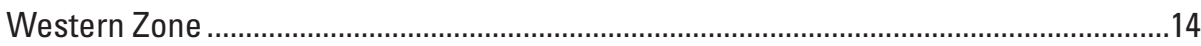

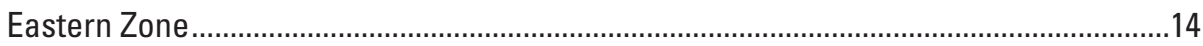

Results of the Content per Kilometer Approach .................................................................14

Diamond-Production Capacity Results .................................................................................19

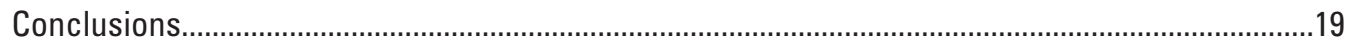

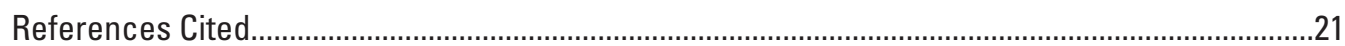

\section{Figures}

1. Map showing the geology of the Central African Republic............................................

2. Map showing the Carnot and Mouka-Ouadda Sandstones, Central African Republic ....7

3. Diagram depicting official diamond transactions, Central African Republic .....................8

4. Map showing diamondiferous contour zones in the western Central African Republic ...............................................................................................10

5. Map showing diamondiferous contour zones in the eastern Central African Republic . 


\section{Tables}

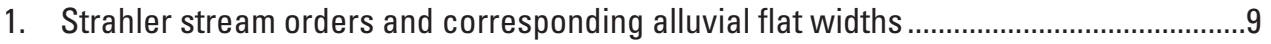

2. Diamond yield per kilometer of stream length .................................................................13

3. Results of the volume and grade approach for calculating total diamond endowment for the western Central African Republic

4. Results of the volume and grade approach for calculating total diamond endowment for the eastern Central African Republic.

5. Results for the content per kilometer approach for calculating total diamond endowment for the western zone, Central African Republic....

6. Results for the content per kilometer approach for calculating total diamond endowment for the eastern zone, Central African Republic

7. Inferred and speculative diamond resources of the eastern plateau, Central African Republic

8. Summary of estimated diamond-resource endowments of the Central African Republic

\section{Conversion Factors}

\begin{tabular}{lcl}
\hline \multicolumn{1}{c}{ Multiply } & \multicolumn{1}{c}{ by } & \multicolumn{1}{c}{ To obtain } \\
\hline meter $(\mathrm{m})$ & 3.281 & foot $(\mathrm{ft})$ \\
kilometer $(\mathrm{km})$ & 0.6214 & mile $(\mathrm{mi})$ \\
square meter $\left(\mathrm{m}^{2}\right)$ & 0.0002471 & acre \\
square kilometer $\left(\mathrm{km}^{2}\right)$ & 247.1 & acre \\
cubic meter $\left(\mathrm{m}^{3}\right)$ & 35.31 & cubic foot $\left(\mathrm{ft}^{3}\right)$ \\
\hline
\end{tabular}




\title{
Alluvial Diamond Resource Potential and Production Capacity Assessment of the Central African Republic
}

\author{
By Peter G. Chirico, ${ }^{1}$ Francis Barthélémy, ${ }^{2}$ and François A. Ngbokoto ${ }^{3}$
}

\section{Abstract}

In May of 2000, a meeting was convened in Kimberley, South Africa, and attended by representatives of the diamond industry and leaders of African governments to develop a certification process intended to assure that rough, exported diamonds were free of conflict concerns. This meeting was supported later in 2000 by the United Nations in a resolution adopted by the General Assembly. By 2002, the Kimberly Process Certification Scheme (KPCS) was ratified and signed by diamond-producing and diamond-importing countries.

Over 70 countries were included as members of the KPCS at the end of 2007.

To prevent trade in "conflict diamonds" while protecting legitimate trade, the KPCS requires that each country set up an internal system of controls to prevent conflict diamonds from entering any imported or exported shipments of rough diamonds. Every diamond or diamond shipment must be accompanied by a Kimberley Process (KP) certificate and be contained in tamper-proof packaging.

The objective of this study was (1) to assess the naturally occurring endowment of diamonds in the Central African Republic (potential resources) based on geological evidence, previous studies, and recent field data and (2) to assess the diamond-production capacity and measure the intensity of mining activity. Several possible methods can be used to estimate the potential diamond resource. However, because there is generally a lack of sufficient and consistent data recording all diamond mining in the Central African Republic and because time to conduct fieldwork and accessibility to the diamond mining areas are limited, two different methodologies were used: the volume and grade approach and the content per kilometer approach.

Estimates are that approximately 39,000,000 carats of alluvial diamonds remain in the eastern and western zones of the CAR combined. This amount is roughly twice the total

\footnotetext{
${ }^{1}$ U.S. Geological Survey, Reston, Virginia.

${ }^{2}$ Bureau de Recherches Géologiques et Minières, France.

${ }^{3}$ Direction Générale des Mines, Central African Republic.
}

amount of diamonds reportedly exported from the Central African Republic since 1931. Production capacity is calculated to be 840,000 carats per year, a number that is nearly twice the 450,000 carats per year reported annually by the Central African Republic. The difference in the two numbers reflects the lack of sufficient data on diamond resource grades, worker productivity, and the number and locations of sites being worked.

\section{Introduction}

\section{Kimberley Process Certification Scheme}

During the late 1990s the issue of "conflict diamonds," or "blood diamonds," became increasingly recognized by the global community, largely due to civil unrest and wars in Sierra Leone and in Angola. In 2001, the United Nations imposed sanctions against the Liberian diamond trade after it accused Liberian President Charles Taylor of supplying weapons and training in exchange for diamonds from the Revolutionary United Front (RUF), which was engaged in a civil war with the government of Sierra Leone. The Democratic Republic of the Congo (DRC) also experienced several civil uprisings during the 1990s, and diamonds were reportedly used to fund rebel forces (Le Billon, 2008).

In May of 2000, a meeting was convened in Kimberley, South Africa, and attended by representatives of the diamond industry and leaders of African governments to develop a certification process intended to assure that rough, exported diamonds were free of conflictual concerns. This meeting was supported later in 2000 by the United Nations in a resolution adopted by the General Assembly. By 2002, the Kimberly Process Certification Scheme (KPCS) was ratified and signed by diamond-producing and diamond-importing countries. Over 70 countries were included as members of the KPCS at the end of 2007.

The KPCS is an international activity whose goal is to prevent trade in conflict diamonds while helping to protect legitimate trade through monitoring of the production, 
exportation, and importation of rough diamonds throughout the world. To accomplish this task, the KPCS requires that each country set up an internal system of controls to prevent conflict diamonds from entering any imported or exported shipments of rough diamonds. Every diamond or diamond shipment must be accompanied by a Kimberley Process (KP) certificate and be contained in tamper-proof packaging. The certificate includes an export origin section, an import verification section, and a security slip. The KP also requires that no diamonds be imported from or exported to a nonmember of the KPCS. Additionally, a recommendation of the KPCS is that all artisanal miners and buyers within a country should be licensed by the host government (Olsson, 2006).

Countries that are members of the scheme are required to report their official amount of diamond imports and exports, as well as the value of the diamonds each year to the KP. These data are then made public and provided to other organizations in order to monitor the official statistics reported by all KP members.

\section{Kimberley Process Verification}

It is often difficult to obtain independent verification of diamond-production statistics provided by KPCS member countries. However, some degree of independent verification can be obtained by combining an understanding of the naturally occurring endowment of diamond resources with the country's diamond-production capacity or intensity of mining activity. Studies integrating these two components can produce an estimated range of production values for a country that can then be compared with the actual reported production statistics. Reported production statistics that fall far outside the estimated possible production values may be further investigated to ensure that infiltration of conflict diamonds from an outside source is not occurring.

Recently, the Bureau de Recherches Géologiques et Minières (BRGM) produced an assessment for the Republic of the Congo (Congo Brazzaville) (Barthélémy and others, 2006). This assessment was acclaimed within the KPCS community as a method for independent verification of alluvial diamond resources. A similar assessment was also conducted by the U.S. Geological Survey (USGS) in Liberia (Wahl and others, 2007). The USGS assessment made substantial contributions to the assessment process of the diamond potential and contributed to a lifting of the sanctions on mining and selling of diamonds imposed on Liberia through the Kimberley Process.

The work of both the BRGM and the USGS in this field continues as the organizations have partnered to conduct independent evaluations of the diamond potential in Mali and the Central African Republic.

\section{Project Objectives}

There are six main objectives of this project:

1. Produce a synthesis of geological and alluvial (placer) diamond-production information for the Central African Republic (CAR) from historical documentation.

2. Develop a model to estimate the endowment of undiscovered diamond resources in the CAR.

3. Use the model to estimate the CAR's production capacity for rough diamonds.

4. Create a detailed geographic information system (GIS) of diamond mining.

5. Transfer to the CAR information resources to monitor diamond mining areas.

6. Develop and conduct a workshop to present the final report results in conjunction with the Central African Republic Direction Général des Mines (DGM).

\section{Work Plan and Timetable}

The CAR evaluation was completed in four phases, from research to a field evaluation to initial report preparation to project finalization. The entire process occurred over a timeframe of approximately 1 year.

\section{Phase 1: Research}

Phase 1 of this study included research, collection, and organization of all available data related to diamond resources and production in the CAR. This endeavor required a significant bibliographic study and the collection of geologic maps, geophysical data, and remotely sensed satellite imagery. During this phase, basic evaluations of the incoming data were conducted to assess its relevance, quality, and importance.

Reports were examined to find all documented occurrences of diamonds and, where possible, the grade recorded at these locations. A digital database of diamond occurrences and grades was compiled to include coordinate information. This database was then mapped to display the spatial distribution of diamond occurrences based on historical field surveys. Phase 1 was completed over the course of 4 months.

\section{Phase 2: Field Evaluation}

The second phase of this project was the field evaluation phase. This phase incorporated all aspects of the planning and execution of on-the-ground field studies and field data collection in the diamond mining areas of the CAR. Also included was time spent developing contacts and working with the scientists and staff of the DGM in Bangui. 
Two field excursions were completed under the scope of this study. The first was composed of project members representing the USGS, the BRGM, and the DGM and occurred in May 2007. The second field excursion occurred in September 2007 and was composed of project members from the BRGM and the DGM.

The fieldwork component of the project identified and characterized the mining regions of the eastern and western parts of the CAR. Fieldwork was conducted in both regions. One team composed of two project scientists visited the western diamondiferous zone. Two teams composed of five project members visited the eastern diamondiferous zone. The main goal of these field excursions was the characterization of the mining areas, evaluation of current artisanal mines, and field data collection.

The goal of the second field season was mainly data development and characterization of diamond-production capacity. Phase 2 was completed over the course of approximately 2 months.

\section{Phase 3: Report Preparation}

Phase 3 incorporated the preparation of the resource assessments and the production capacity estimates. All field data were compiled, organized digitally, and analyzed. The GIS database was developed using both the data gained from the historical research as well as the field surveys from phase 2. Once the compilation and analysis of the data and the GIS database were complete, this final report was written. Phase 3 was completed over the course of 5 months.

\section{Phase 4: Project Finalization}

The final phase of the project was the presentation and final discussions of the project report. An in-country workshop was organized to include both practical fieldwork-oriented training and discussions of the project report among the team members. After the workshop and training were completed, the reports were finalized to reflect the discussions and recommendations of the team members and delivered to all parties involved. Phase 4 was completed over the course of 2 months.

\section{Team Organization}

This project was supported by the Economic Support Fund (ESF) provided by the U.S. Department of State and was executed by a trilateral partnership of scientists and technical professionals from the USGS, the BRGM, and the DGM of the Central African Republic.

Peter G. Chirico, USGS, Project Chief, Geographer Emily Phillips, USGS, Researcher Michael Warner, USGS, GIS/Remote Sensing Analyst François M.J. Lampietti, USGS, Consulting Economic Geologist
Francis Barthélémy, BRGM, Geologist

Yves Husson, BRGM, Geologist

Alain Lambert, BRGM, Geologist

Jean-Michele Eberlé, BRGM, Diamond Expert, Geologist

Jean Sylvain Feïgoudozouï, DGM, Directeur Générale des Mines

Richard Ricardo Bangoto, DGM, Charge de Mission des Mines

François Alain Ngbokoto, DGM, Mining Engineer

Fernand Nanibet, DGM, Geologist

In addition, the field staff was aided by the Gendarme Mining Police.

Eloi-Arthur Ouazounam, Maréchal des Logis

Isaac Nanbeam, Gendarme $1^{\text {st }}$ Class

Maioret Vicko, Gendarme $1^{\text {st }}$ Class

Gabriel Koae, Gendarme $2^{\text {nd }}$ Class

Michel Toute-Nzola, Gendarme $2^{\text {nd }}$ Class

Leon Suge Simon, Gendarme

\section{Geologic Description of the Central African Republic with a Focus on Diamond Areas}

\section{Introduction to the Geology of the Central African Republic}

The underlying geology of the CAR consists mainly of basement rocks of Archean and Proterozoic age, which can be divided into two main geologic groups: a granitic-gneissic complex and a schist-quartzitic complex. The granitic-gneissic complex is probably of Neoarchean age and is composed of gneissic, granite, and amphibolitic rocks. Also included in this group of basement rocks is a series of sedimentary volcanic sequences that are typically referred to as "greenstones." Overlying the Archean basement rocks is the schist-quartzitic complex, which is thought to be of Neoproterozoic age and is composed of quartzitic and schistose rocks that are only weakly metamorphosed and generally folded. Both of these complexes are intruded throughout the country by basic rocks of Neoproterozoic age (Schlüter, 2006).

Overlying these older rocks is a sequence of Paleozoic rocks. The two major Paleozoic formations are the Mambéré Formation located in the western CAR and the Kombélé Formation located in the eastern CAR (fig. 1). Both Paleozoic formations are of glacial origin. The Mambéré Formation is a tillite composed of both basal and flow tills as well as reworked glacial deposits derived from sandstone, conglomeratic sandstone, and siltstone that occur in continuous beds, 


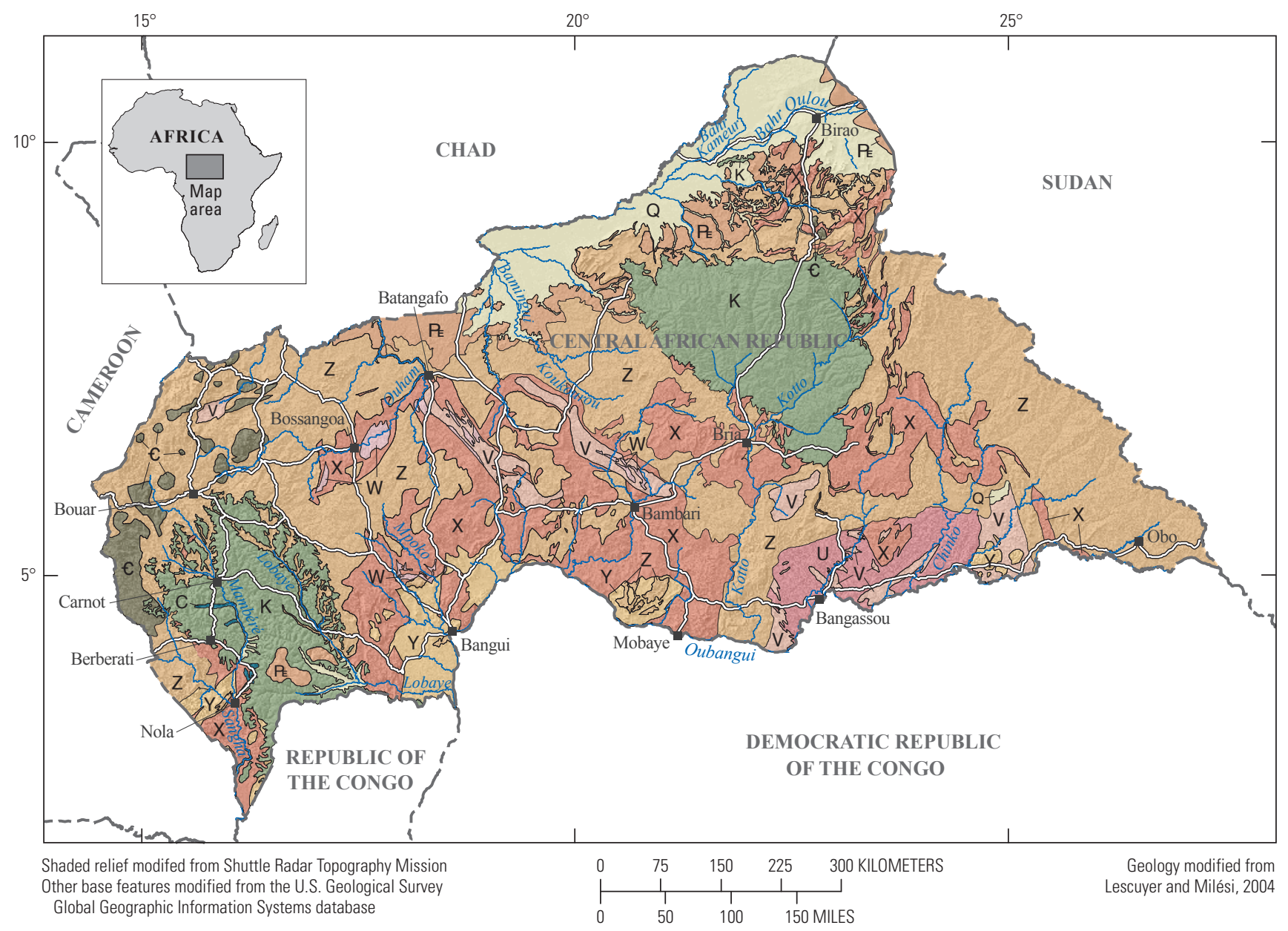

\section{EXPLANATION}

\begin{tabular}{|c|c|}
\hline $\mathrm{Q}$ & Quaternary \\
\hline $\mathrm{PE}$ & Paleogene \\
\cline { 1 - 1 } $\mathrm{K}$ & Cretaceous \\
\cline { 1 - 1 } $\mathrm{C}$ & Carboniferous \\
\hline
\end{tabular}

\begin{tabular}{|c|}
\hline$\in$ \\
\hline$Z$ \\
\hline$Y$ \\
\hline$X$ \\
\hline
\end{tabular}

Cambrian

Neoproterozoic

Mesoproterozoic

\begin{tabular}{|c|c|}
\hline W & Neoarchean \\
\hline $\mathrm{V}$ & Mesoarchean \\
\hline U & Paleoarchean \\
\hline
\end{tabular}

Figure 1. The geology of the Central African Republic.

lenses, and isolated blocks (Censier and Lang, 1992). Similarly, the Kombélé Formation is a conglomeratic sandstone tillite composed of glacial-outwash plain sediments (Censier and others, 1992). Both the Mambéré and the Kombélé Formations generally range in thickness from 30 to 50 meters $(\mathrm{m})$ and are covered by Cretaceous sandstone units lying unconformably above them. The exact areal extent of the Paleozoic rocks is not known because the more recent Mesozoic geology conceals a great deal of them. The Paleozoic units crop out in selected locations at the margins and in selected river valleys where the Mesozoic units have been completely eroded (Censier, 1996).
The Mesozoic, probably Cretaceous, fluvial sequences of conglomeritic sandstones concealing the Paleozoic glacial tillites form two distinct plateaus, one in the east and one in the west. The western plateau is made up of the Carnot Sandstone, and the eastern plateau is composed of the Mouka-Ouadda Sandstone. At one time, these two sandstone units extended much farther south and somewhat farther north than they do today. Later erosion of these two formations developed the current plateau landforms, which characterize the eastern and western CAR landscape (Censier and Tourenq, 1986; Censier, 1996). These two sandstone units are widely reported to be the secondary hosts of the diamonds in the CAR. 
A series of Cenozoic rocks occurs in two distinct zones within the CAR. The first is a series Paleo-Tchadienne continental terminal sandstones extending north of Batangafo to the northern border of the CAR, forming smaller distinct plateaus. The second is the Bambio Sandstone, which is generally located between Nola and Boda just north of the Bangui River in the southwestern part of the country. The Bambio Sandstone lies atop the Carnot Sandstone but only covers an area of approximately 1,700 square kilometers $\left(\mathrm{km}^{2}\right)$.

Recent Pleistocene deposits have filled in the northern basin and are generally divided into either Neo-Tchadienne alluvium or recent alluvial deposits. Quaternary alluvial deposits are also found in the many riverine floodplains throughout the country. Chemical weathering, which is typical in the humid tropical environment, has created lateritic duricrusts and ferricretes during the Quaternary. The weathering crusts may be as thick as $40 \mathrm{~m}$ in places and extend over large portions of the topography throughout the CAR (Petit, 1985; Beauvais, 1989; Beauvais and Roquin, 1996).

\section{Carnot Sandstone}

The Carnot Sandstone is of Mesozoic age and of fluviatile origin, which, in the most recent depositional environments, may have also included lacustrine and palustrine deposits. As a result, the formation is composed of several successional layers of conglomerates, sandstones and mudstones, and siltstones. It lies in the southwestern part of the CAR and covers an area of more than $40,000 \mathrm{~km}^{2}$. The thickness of the unit is highly variable but has been reported to be as thick as 300 to $400 \mathrm{~m}$ in places (Censier, 1990). Heavy mineral and quartz exoscopic analysis (Censier, 1990) demonstrate that the detrital material of the Carnot came from a southerly origin, has similar mineralogical composition throughout the whole infilled basin, and was composed of reworked detrital formations. The Nola and Bolé River series was originally thought to be the source of the reworked material. Subsequent analysis supports the assigning of the glacial Devonian-Carboniferous Mambéré Formation and the Precambrian schist and quartzite rocks as the source of the detrital materials that have been reworked and cemented into the Carnot Sandstone. The underlying Precambrian granitic-gneissic complex of rocks formed the landscape for Carnot deposition (Censier and Lang, 1999). The paleogeography and paleotopography show that this landscape was a general peneplain with monadnocks. The monadnocks' subsequent erosion causes the mineralogical heterogeneities in the current landscape and also results in the irregularities in the basal surface of the Carnot Sandstone. The surface of the original sedimentary basin was much larger than has been interpreted on the basis of current limits of the Carnot Sandstone. The western margin may have extended beyond the CAR and Cameroon border (Censier, 1990).

Deposition of the reworked material occurred from the Albian to the Maastrichtian in north-northwest- flowing riverine braided channels flowing into the Doba Trough
(Chad) and into the Touboro Basin (Cameroon) (Censier and Lang, 1999). Subsequent uplift and faulting during the Cenozoic reversed the direction of flow and erosion of the Carnot from north-northwest to south-southeast and emplaced the current fluvial drainage system.

\section{Mouka-Ouadda Sandstone}

The Mouka-Ouadda Sandstone is a Cretaceous fluviatile sandstone that lies in the eastern Central African Republic. It is thought to be the secondary host rock of the alluvial diamond deposits in the region. The Mouka-Ouadda Sandstone covers an area of approximately $40,000 \mathrm{~km}^{2}$, forming a plateau that is generally less than $500 \mathrm{~m}$ thick. It is composed of layers of sandstone and conglomerate. Similar to that of the Carnot Sandstone, the Mouka-Ouadda is thought to have been derived from detrital material from the fluvial-glacial Kombélé Formation and from the Precambrian schist and quartzite complex and was also deposited on a peneplained Precambrian graniticgneissic basement. Paleocurrent measurements indicate that the major source of sediment lies to the south-southwest, and the direction of deposition was to the north-northeast. As structural evolution of the landscape progressed, the orogenic uplift to the north reversed the riverine flow, thus developing the current drainage system (Malingbar and others, 2006).

\section{Ferricrete Duricrust}

Duricrust is a general term for a surficial crust that is formed by the accumulation of soluble minerals deposited by mineral-bearing water that moves up the weathering soil profile during wet periods and evaporates down the profile in dry periods. Central Africa is home to large swaths of ferruginous duricrusts typically named ferricretes. The ferricretes in the CAR cover large portions of the country and are typically characterized by a crust that ranges in thickness from tens of centimeters to tens of meters and that in turn is lying upon a lateritic weathering soil profile. The ferricretes in central Africa are the result of paleoclimatic evolution over the past approximately 150 million years. Different geomorphic types of ferricretes have been characterized. Beauvais (1989) has described three ferricrete systems present in the CAR that relate to high plateaus, hillslopes, and low plateaus. Mineralogically, the high plateaus are the most evolved and thicker and rich in hematite and kaolinite. Ferricretes developing on hillslopes are softer crusts containing goethite and kaolininte, and the thinnest and least evolved ferricretes are present on the low plateaus. Ferricretes that mineralogically contain more hematite tend to correspond to less humid and generally warmer paleoclimates that have been present in the CAR throughout the past 70 million years (Tardy and others, 1991). Beauvais and Roquin (1996) suggest that the ferrricretes in the CAR reflect the processes of erosion and weathering more than they reflect the parent material of the underlying bedrock, although there tends to be more influence of the underlying 
Alluvial Diamond Resource Potential and Production Capacity Assessment of the Central African Republic

bedrock in the hillslope and low plateau ferricretes than in the high plateau ferricretes. High plateau and hillslope ferricretes studied in the southeastern CAR are 10 to $12 \mathrm{~m}$ thick, with the top 3-4 m composed of the massive or protonodular facies (Beauvais, 1999).

\section{Source of Diamond Occurrences}

No kimberlites, lamproites, or other primary geologic deposits of diamonds have been discovered in the CAR. The current understanding of the geologic origin of the diamonds in the region is that the original kimberlites from which CAR diamonds were eroded may lie undiscovered in the northern part of the Democratic Republic of the Congo. Again, no direct evidence for this exists, but Censier (1996) claims that tectonic, mineralogical, and crystallographic evidence strongly support this interpretation.

Kimberlitic intrusions occurred in the Central African region during the Mesoproterozoic (Kibarian) and more recently during the Early Cretaceous (Giresse, 2005). Because the diamonds are entrained in the Upper Cretaceous (from Albian to Maastrichtian) Carnot and Mouka-Ouadda Sandstones, Censier (1996) proposes that it is unlikely that the diamonds' primary source would be from kimberlitic intrusions during the Early Cretaceous. If the primary kimberlitic source of the CAR diamonds is from the Precambrian, as is the case of the nearest kimberlite pipe located in Mitzic, Gabon, it is possible that the diamonds in the CAR may have been deposited and reworked two or three times (Demptser and Tutusaus, 1995). In any event, the likely location of the primary kimberlitic sources is assumed to be in the northern region of the DRC. It is interesting to note that much of the northern area of the DRC is covered by Quaternary sediments that may be covering geologic evidence of primary kimberlitic source rocks, if they exist.

Diamonds are believed to be hosted by Mouka-Ouadda and Carnot Sandstones as secondary source rocks. It is possible that the Paleozoic formations underlying the Mesozoic sandstone plateaus may also be secondary source rocks for diamonds, but that has not been proven by direct evidence. Despite sampling of the Carnot and Mouka-Ouadda Sandstones, no direct indications of diamonds in the sandstones have been discovered either. The diamonds are found in recent alluvial terraces and flood-plain deposits lying both on top of the sandstone plateaus and in detrital valleys eroding the plateaus.

The Central African Republic is also host to a type of diamond called a "carbonado." Carbonados are defined as an "opaque aggregate composed of minute diamond particles forming a mass with a granular structure and superior toughness" (Bates and Jackson, 1984). This diamond type was first observed in Brazil and parts of Venezuela as early as the 1840s. The term carbonado is itself of Brazilian origin. The polycrystalline structure of the carbonado makes it extremely durable; therefore, it has been in great demand for use in industrial applications such as cutting tools and drilling equipment. It has been estimated that up to 30 percent of the diamonds in the western zone and 7 percent in the eastern zone of the CAR are of the carbonado variety (Erlich and Hausel, 2002).

Diamond occurrences outside the immediate areas of the two secondary plateaus do exist and may be from either the plateaus themselves or from other isolated occurrences. It is understood that the two Cretaceous sandstone formations covered a much larger area in the past than they do at present, and diamond occurrences that are far from the current extent of the Cretaceous formations may in fact originate from eroded remnants of the same formations.

As the Cretaceous sandstone plateaus erode, diamonds are liberated from the secondary host rock. The liberated diamonds are washed downstream and deposited in recent Quaternary alluvium and terrace deposits along the river courses. Three alluvial placer deposit types have been observed: alluvial flat and channel deposits, low terrace deposits, and high terrace deposits.

\section{Alluvial Diamond Deposits}

The Central African Republic has been host to the geologic, tectonic, and climatic environment that has developed a geomorphology conducive to the formation of placer deposits. The first factor controlling development of the placer deposit is the presence of nearby, although undiscovered, primary diamond mineralization. Secondly, the tectonic setting in which the Cretaceous sandstones have been uplifted, reversing the flow direction of the river systems and subsequently eroding them, has created an environment where erosion of the secondary host rocks liberates the diamonds and redeposits them in alluvial deposits in the river valleys.

Over the past 100 million years (Ma) the climatic conditions in the CAR have fluctuated between wetter periods and drier periods. From the Late Albian $(\sim 100 \mathrm{Ma})$ the Congo Basin experienced widespread humid conditions, but during the Late Cretaceous to Paleogene ( $\sim 65 \mathrm{Ma})$ there was a marked drying trend throughout the basin which includes some areas being exposed to eolian mobilization of sediments (Giresse, 2005). Subsequently, during the Neogene ( 23 Ma) wetter conditions re-emerged. This fluctuation allows for the liberation and erosion of diamonds during wetter periods and the concentration of diamonds in alluvial deposits during the drier periods. Burton and Fralick (2003) showed that long intervals of average flows interspersed with large-scale flooding events are the optimum conditions for the formation of longitudinal placer development. This scenario seems consistent with the depositional history of the CAR alluvial materials. Consequently, the alluvial geomorphology of the current-day landscape is an important factor in the location of diamond placer reserves (Sutherland, 1985). 
For the purposes of this report, the alluvial diamond deposits are divided into two main diamondiferous areas: one in the west, which is associated with the Carnot Sandstone and occurs in the Kadéi-Mambéré-Sangha region, and one that lies in the east and is associated with the Mouka-Ouadda Sandstone in the Haute-Kotto region (fig. 2). Censier (1996) asserts that both areas are entirely diamondiferous owing to the large number of rivers that local diggers have been exploiting with alluvial workings. Previous studies had postulated that only the lower members of the Cretaceous sandstone layers were diamondiferous. However, diamonds have been recovered only in the alluvial material despite many studies that have tested the sandstones and conglomerates directly for diamonds (Censier, 1996).

\section{History of Diamond Mining and Production}

Diamonds were discovered in the CAR in 1914 and again in 1929 when the widespread presence of alluvial diamond deposits was recognized (Dempster and Tutusaus, 1995). Commercial mining and production began in 1931 in the Bossangoa and Nola regions (western region) and rapidly expanded from 1935 to 1945 . The alluvial exploitation of the eastern region expanded from 1943 to the present. Several mining companies exclusively exploited the diamond resources in the CAR from 1931 until 1960, and diamond production remained relatively low, averaging about 75,000 to

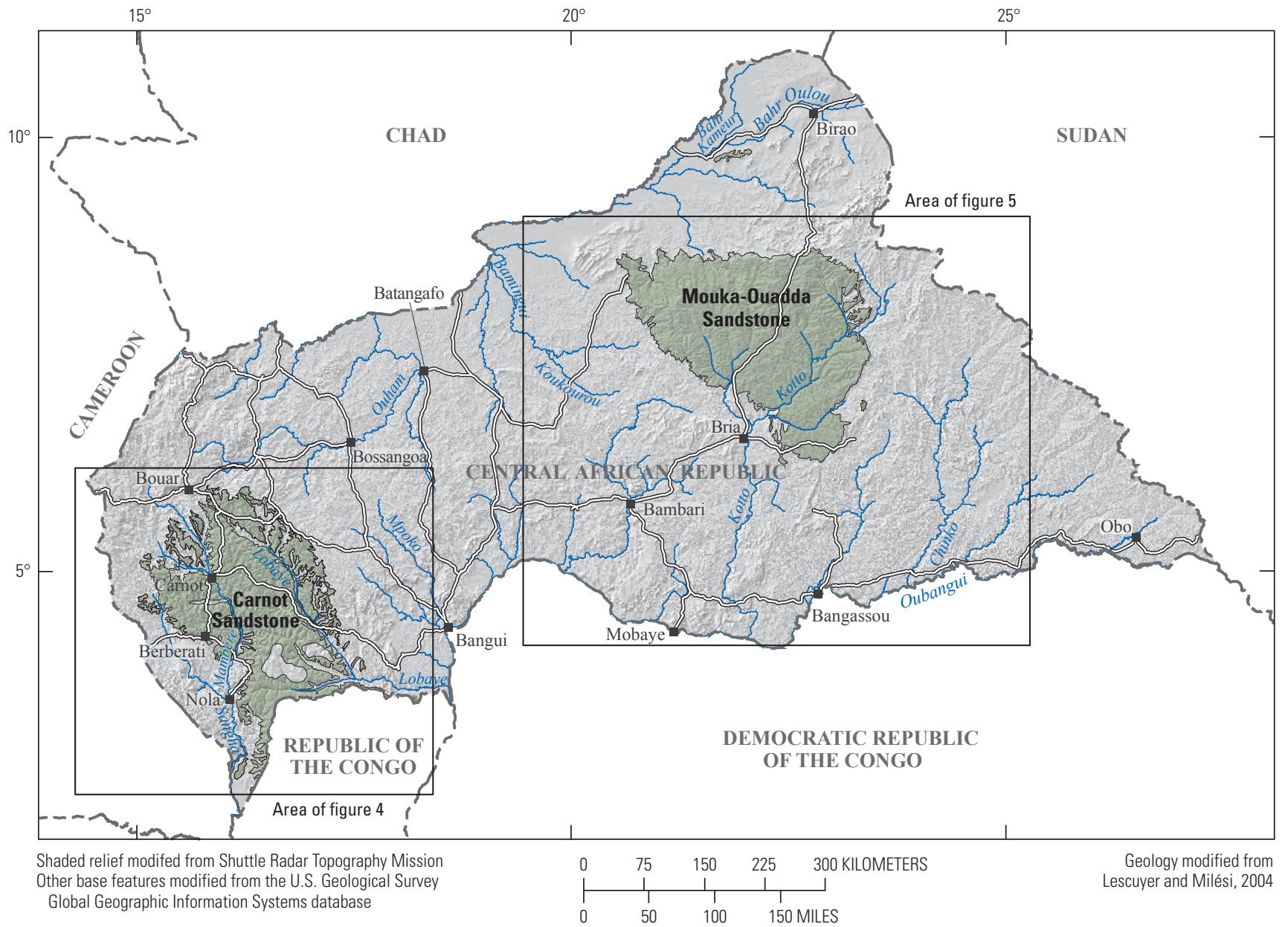

Figure 2. The Carnot and Mouka-Ouadda Sandstones, Central African Republic. 
100,000 carats per year. In 1960, the Central African Republic gained independence and shortly thereafter, in April 1961, authorized the Bureau d'Achat to act as an organization of diamond export companies. In addition, the government of the CAR began licensing artisanal miners who, in turn, hired diggers to exploit the alluvial deposits. From 1961 through the early 1970s, production of diamonds increased rapidly from approximately 100,000 carats a year to approximately 450,000 carats a year. The increase was largely due to the authorization and introduction of artisanal miners working throughout the sector. Annual production of diamonds varies from year to year in relation to the seasonal environmental conditions, stability and security within the country, and the number of diggers employed in the sector.

As of 2006, there were 7 Bureaux d'Achat and 18 Centre $d$ 'Achat acting as buyers and diamond exporters. There are estimated to be approximately 300 collecteurs who purchase the diamonds locally from artisans close to the alluvial mining sites and resell them to the Bureau d'Achat for sale and export. There are 1,988 artisanal miners and 6,515 ouvrier miniers for a total of 8,503 artisanal miners. Ouvrier miniers are licensed artisans who work on smaller scales and pay less of a licensing fee than the other artisanal miners. Each artisanal miner hires a team of diggers, which may range in size from 6 to 15 persons. There are also a few small-scale mining companies that operate in the CAR either through hiring diggers to exploit the deposits or by acting as buyers, collecteurs, and exporters.

It is estimated that between 50,000 and 100,000 diggers are exploiting alluvial diamond deposits in the CAR. Dietrich (2003) has reported the total number of licensed artisanal diggers as being approximately 50,000, while Censier (1996) reported an estimated 70,000. According to a 2003 unpublished report by Koyatro (Direction Générale des Mines), it is estimated that the total number of diggers is around 70,000 and that teams are typically constituted of approximately 10 to 15 diggers. Each team is hired and organized by a licensed artisan. Licensed artisans may sell diamonds either to a collecteur or directly to one of the registered diamond buying offices composing the Bureau d'Achat. The collecteurs may buy diamonds from many artisans and generally act as middlemen between the artisan and the bureau (fig. 3).

In 1982, the Bureau d'Evaluation et de Contrôle de Diamant et d'Or (BECDOR) was established to officially value all diamond and gold exports. BECDOR assesses the value of all official diamond exports from the CAR and collects official statistics on diamond and gold production within the CAR. BECDOR also evaluates the receipts of sale from artisans and export companies operating in the CAR for all diamonds that they have purchased from artisans and mining societies. Each diamond sale is recorded through a series of receipts listed

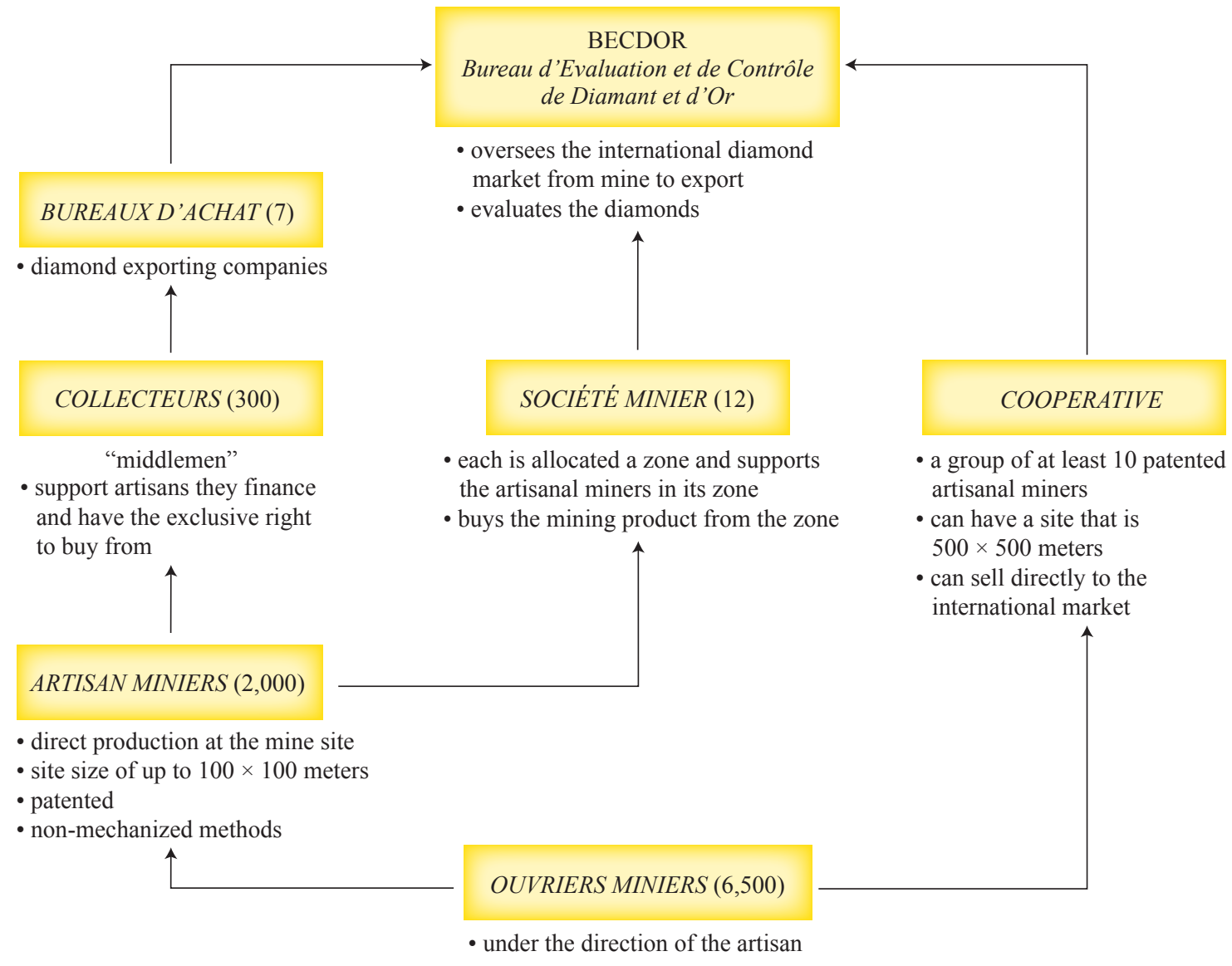

Figure 3. Official diamond transactions, Central African Republic. 
with the buyer's and seller's names and license numbers, in addition to carat, value, and place of origin of the diamonds.

Artisans and the teams of diggers that they employ utilize little if any mining technology beyond the occasional pumps. Most continue to use hand tools, sieves, jigs, and local timber and wood resources to perform the mining activities. Therefore, there are few barriers to entry for diamond diggers, as little or no training is required and basic tools are used. Often diggers move seasonally from site to site as new deposits are mined or as variations in the farming seasons occur.

While there are teams of 6 to 15 diggers typically employed by the artisans, there are often a number of ancillary workers at mine sites. These ancillary workers are usually family members of the diggers and include their wives and children. Women and children perform tasks such as transporting, washing, and sorting the gravel ore. Consequently, at a site where an artisan has a team of 10 diggers, there may be as many as 50 individuals working throughout all phases of the extraction and production process.

In addition, at some larger mine sites, women were observed cooking and selling food to the mine workers, operating independently of any specific digger family group. Markets may also be located close to the mine sites on certain days, developing a small-scale informal economy that may consist of all types of food and material sales and services.

\section{Methodology for Assessing the Central African Republic Diamond Resource Potential}

The objective of this study was twofold. The first goal was to assess the naturally occurring endowment of diamonds in the CAR, which can be termed the "potential diamond resources," on the basis of geologic evidence, previous studies, and recent field data collection. The second goal was to assess diamond-production capacity through an understanding of current human and resource conditions in the CAR and to measure the intensity of mining activity. A degree of independent analysis is reached by assessing both the potential resources and the production capacity and comparing these data with the published diamond-production figures from the CAR.

Several possible methods can be used to estimate the potential diamond resource. However, because there is generally a lack of sufficient and consistent data recording all diamond mining in the CAR and because time to conduct fieldwork and accessibility to the diamond mining areas are limited, two different methodologies were used in this study to assess the diamond potential. The results of these two methods were cross-checked with one another to help provide clarification and redundancy in error checking.

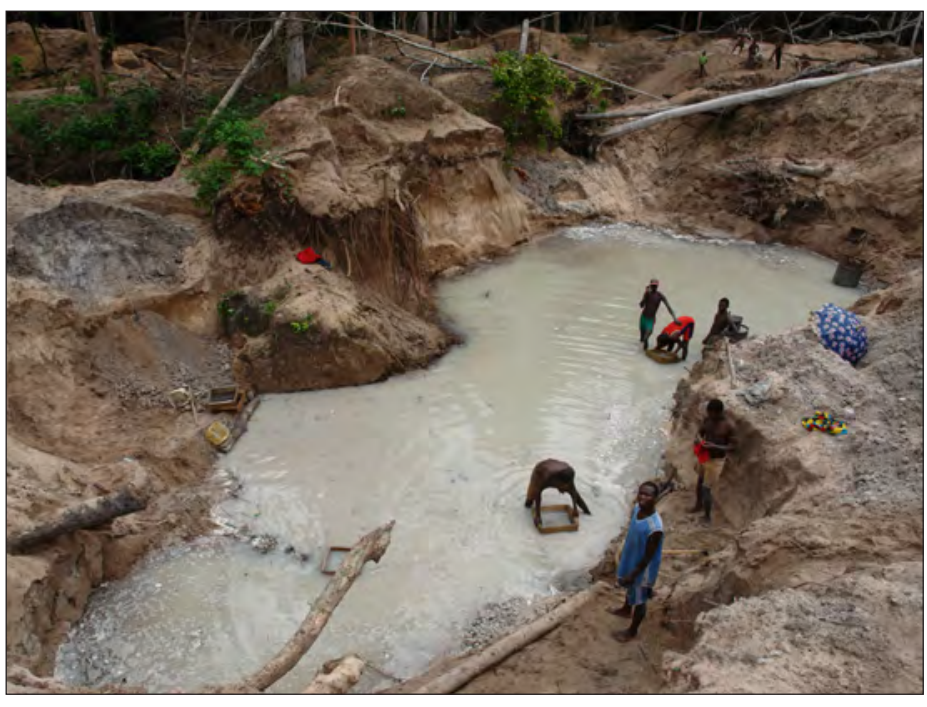

Artisanal diamond miners washing gravels near Wango, CAR, May 2007

\section{Field Data Collection and Basic Research}

An extensive search for literature on the geology and diamond mining of the CAR was performed under the scope of this study. The purpose behind completing a bibliographic research study was to determine the extent of data that have already been collected and that may prove useful in the development of diamond mining assessments and general geologic background. Information on diamond mining sites, techniques, grades of diamond workings, and the history of diamond mining was extracted from many different publications and developed into a database of all diamond showings. The database was then used to extract key parameters for both the eastern and western CAR diamond deposits. These parameters populate the tables presented in this study.

In addition, data collected during the field campaigns provided valuable information on the number of artisans and diamond diggers operating in the country. Also, information about the productivity of diamond workings and the amount of overburden at specific sites was measured and recorded. Site visits revealed the nature of the diamond deposit, the thickness of the gravel layers being mined, and the geomorphologic deposit type. To accurately gather the information from the field, a comprehensive questionnaire was developed and used.

Each field team was provided a set of questionnaire booklets. The booklets contained blank forms which the field teams filled out at every site that was visited during the field study. It was important to record spatial location of the mine sites accurately (longitude and latitude) as well as mine conditions. Mine conditions may have included the size and depth of the mine, the distance from the closest river, town, and road, the depth of the overburden, or the thickness of the gravel. In addition, questions were asked regarding the flow of production, number of miners and teams, and additional 
jobs noted in the surrounding areas. The standardized questionnaire ensured that a consistent set of data was gathered at each site, even though the teams were working separately at different sites throughout the country. The field data gathered through this method were incorporated into the database of diamond occurrences.

A map database of alluvial diamond diggings, workings, mine sites, and diamond recoveries was used to develop the current active mining diamondiferous deposit zones within the western and the eastern CAR (fig. 2). The zones were developed in a GIS by grouping diamond showings into contiguous groups spatially. These contoured zones are used in both methodological assessments to limit the calculations to the areas most actively being mined within the CAR. The contour zones for the western diamond deposits are shown in figure 4, and contour zones for the eastern zone diamond deposits are shown in figure 5. Rivers lying between contoured zones are also included in the assessments. These rivers are Strahler

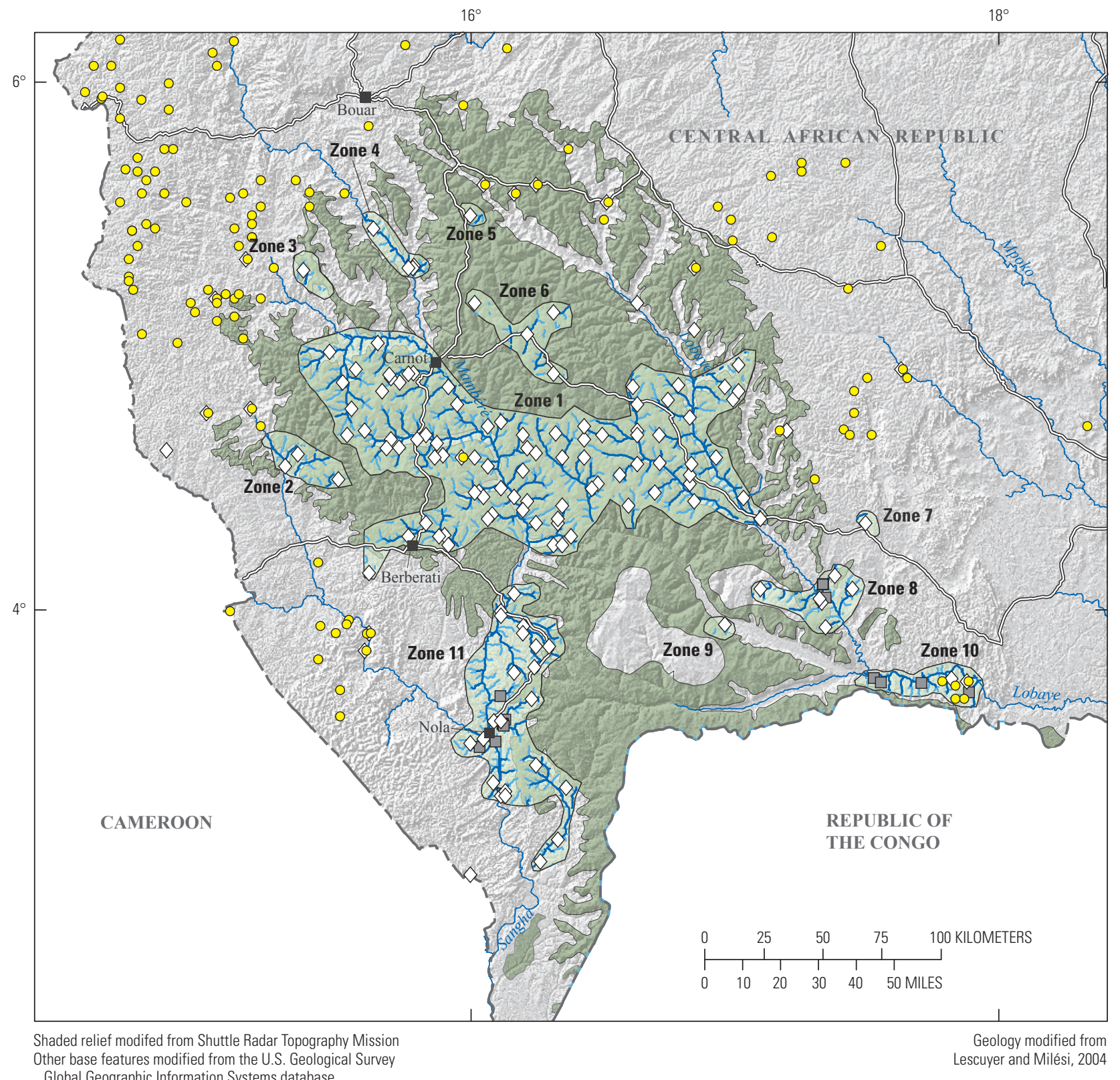

EXPLANATION

\begin{tabular}{lll}
$\square$ & Carnot Sandstone & $\diamond$ Diamond showing \\
$\square$ Contour zone and number & $\bigcirc$ Gold showing \\
\hline$\quad$ Major stream & $\square$ USGS/ BRGM study site \\
\hline$\quad$ Minor stream &
\end{tabular}

Figure 4. Diamondiferous contour zones in the western Central African Republic. 


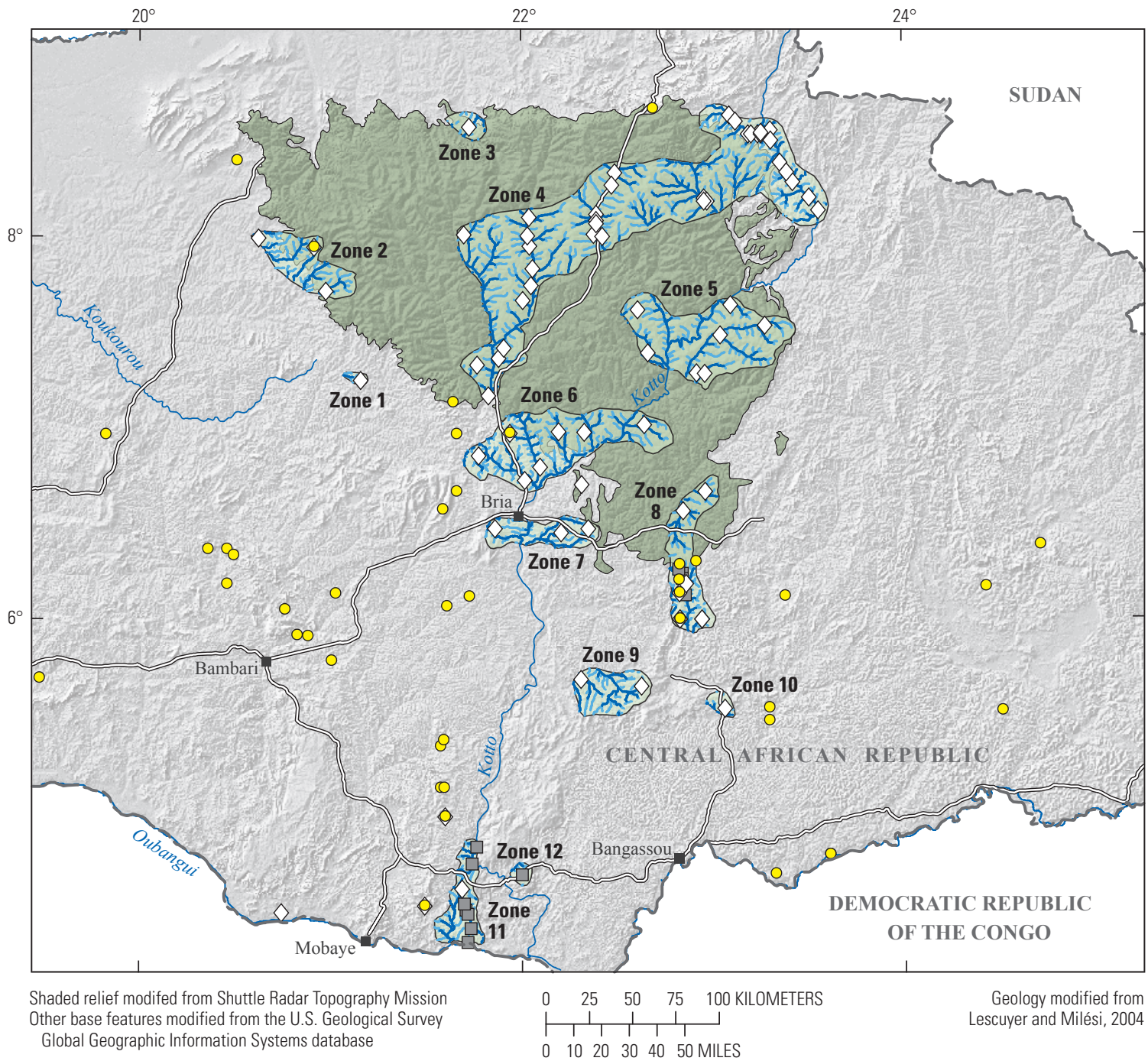

EXPLANATION

\begin{tabular}{lll}
$\square$ & Mouka-Ouadda Sandstone & $\diamond$ Diamond showing \\
$\square$ Contour zone and number & $\circ$ Gold showing \\
$\square \quad$ Major stream & $\square$ USGS/ BRGM study site \\
\hline & Minor stream &
\end{tabular}

Figure 5. Diamondiferous contour zones in the eastern Central African Republic. 
orders 6,7 , and 8 and represent large rivers with significant potential to have alluvial diamond deposits. The larger order rivers are included in the assessment calculations as complementary areas. The results from these areas are contained in the tables for the eastern and western zones, respectively, but are entered separately to distinguish between deposits in areas of active diamond showings and areas of significant potential that have no recorded active diamond diggings.

The first approach estimates a volume of alluvial material in the contoured diamondiferous deposit zones and assigns a diamond ore grade for each cubic meter of alluvium. The second method uses a cumulative river length for contoured diamondiferous deposit zones and assigns a diamond grade for the different lengths of stream based on how rich the alluvial material along those selected stream reaches may be.

For each method, historical data were collected on the diamond grades, excavations, and yields for each of the diamondiferous zones. A digital elevation model (DEM) was used to derive the streams and rivers and overall database of the hydrologic drainage system of the country. The calculation of linear length values of the drainage network was measured using a GIS.

\section{Volume and Grade Approach}

The volume and grade methodological approach can be described mathematically as:

$$
P=(V \times T 1)+(1 / 4 V \times T 2),
$$

where

$$
\begin{aligned}
& P \quad \text { is the estimated diamond resource potential, } \\
& \text { and } \\
& V \quad \text { is the volume of alluvium. }
\end{aligned}
$$

The volume of alluvium is determined, in this method, by estimating the width of the alluvial flat deposit and multiplying it by the thickness of the gravel layer being mined. The product of this multiplication yields a number equal to the volume of diamondiferous gravel. Alluvial flat widths are determined by assigning a width based on the order of the river or stream.

Stream ordering is a process whereby a river system channel-network map is analyzed quantitatively. The smallest tributaries in the uppermost portions of watershed are assigned an order of one. They are the smallest and shortest segments of the riverine network. When two first-order streams come together, a second-order stream is formed. Only when two second-order streams join is a third-order stream formed. This analysis continues until all streams and river channels in the network have been classified. The logic behind the stream ordering system developed by Strahler (1964) is that order number is directly proportional to the size of the contributing watershed, to channel dimensions, and to stream discharge measurements for each stream segment.
Following this logic, the widths of the alluvial flats along stream segments of the same order will be proportional. The flat widths have been determined by previous studies (Barthélémy and others, 2006) and secondarily verified and modified by field observations. Table 1 demonstrates how each stream is assigned an alluvial width based on its order.

For each alluvial flat width there is also a corresponding measurement of the thickness of the gravel layer within the alluvial deposit that is known to be diamondiferous. Again, the values of the gravel thickness are modeled from previous studies in central Africa and are based on recent field observations. The thickness of gravel layers corresponds to the order of the streams because larger higher order streams have a greater depositional history and have been verified in the field to have larger and thicker gravel deposits.

The gravel layers are not all equally endowed with the same content of diamonds. Different gravel deposits within the alluvial flats may have higher concentrations on the basis of depositional history, the type of fluvial environment present, and the time period during which the alluvial gravels were originally deposited. To account for these variations in depositional history, two gravel grades are used in the formula. One grade is described as the "basic" grade and is applied to all of the alluvial gravels calculated for the volume. The second grade is the "concentration" grade. This value is applied only to one-fourth of the total calculated volume of alluvial gravel in the deposit.

$T 1$ corresponds to the "basic" grade and is applied to the entire volume of the alluvial flat. The basic grades are determined from previous field observations listed in the tables according to the study area. They are either determined as an average of field sampling results or they are a weighted average.

$T 2$ corresponds to the "concentration" grade of the alluvial gravels. This grade accounts for the fact that diamond occurrences are not uniformly consistent throughout the

Table 1. Strahler (1964) stream orders and corresponding alluvial flat widths.

\begin{tabular}{ccc}
\hline $\begin{array}{c}\text { Strahler } \\
\text { stream order }\end{array}$ & $\begin{array}{c}\text { Width of alluvial flat } \\
\text { (meters) }\end{array}$ & $\begin{array}{c}\text { Thickness of } \\
\text { diamondiferous } \\
\text { gravel layer } \\
\text { (meters) }\end{array}$ \\
\hline 1 & 5 & 0.15 \\
2 & 10 & 0.20 \\
3 & 20 & 0.30 \\
4 & 30 & 0.40 \\
5 & 40 & 0.50 \\
7 & 50 & 0.60 \\
8 & 70 & 0.80 \\
& 100 & 1.00 \\
\hline
\end{tabular}


entire deposit. In addition, previous studies have determined that artisanal miners are unlikely to work gravels where the grade is less than 0.1 to 0.2 carats per cubic meter $\left(\mathrm{kt} / \mathrm{m}^{3}\right)$ (Barthélémy and others, 2006). There are exceptions to this, where artisanal diggers may dig in the hope of finding a rare but single large stone in an otherwise very low-grade deposit.

Certain areas that fall outside the contoured zones have been included in the volume and grade assessment approach as complementary areas that interconnect the contoured zones. In particular, rivers and streams of Strahler orders 6, 7, and 8 that connect diamondiferous contour zones or flow from them have been included.

\section{Content per Kilometer Approach}

Bardet (1974) proposed another possible approach to determining the potential diamond resources of the Central African Republic's alluvial deposits. It involves assessing the grade of the diamond resources as a function of the carats recovered per kilometer of length of the stream or river along which they are recovered. His studies classified rivers and streams as being in one of three general categories: very rich, rich, or poor. Bardet assigned ranges of values of grades from 400 carats per kilometer (kt/km) to $10,000 \mathrm{kt} / \mathrm{km}$ to each of the categories. The fieldwork conducted by the team determined the following categories of diamondiferous content per kilometer for rivers, presented in table 2.

Following this categorization, this study used a modified version of Bardet's approach, which can be expressed by the formula:

$$
\begin{gathered}
\mathrm{R}_{\text {total }}=(L 1 \times T 1)+(L 2 \times T 2)+(L 3 \times T 3), \\
\text { and where } \mathrm{R}_{\text {concentrated }}=(V 2 \times T 2)+(V 3 \times T 3) .
\end{gathered}
$$

Each contoured zone was assigned an average diamond grade per kilometer of stream length. These grades correspond to $T 1$ for very rich, $T 2$ for rich, and $T 3$ for poor. The total length of streams within each study area is calculated. The total length of streams that fall into each of the categories (very rich, rich, and poor) was then calculated from the total and assigned to each of the $L 1, L 2$, and $L 3$ variables. These two parameters

Table 2. Diamond yield per kilometer of stream length.

[kt/km, carat per kilometer]

\begin{tabular}{rccc}
\hline Zone & $\begin{array}{c}\boldsymbol{T 1}- \\
\text { Very rich streams } \\
(\mathbf{k t} / \mathbf{k m})\end{array}$ & $\begin{array}{c}\text { T2- } \\
\text { Rich streams } \\
(\mathbf{k t} / \mathbf{k m})\end{array}$ & $\begin{array}{c}\text { T3- } \\
\text { Poor streams } \\
(\mathbf{k t} / \mathbf{k m})\end{array}$ \\
\hline Eastern & 6,000 & 1,500 & 500 \\
Western & 7,500 & 2,500 & 850 \\
\hline
\end{tabular}

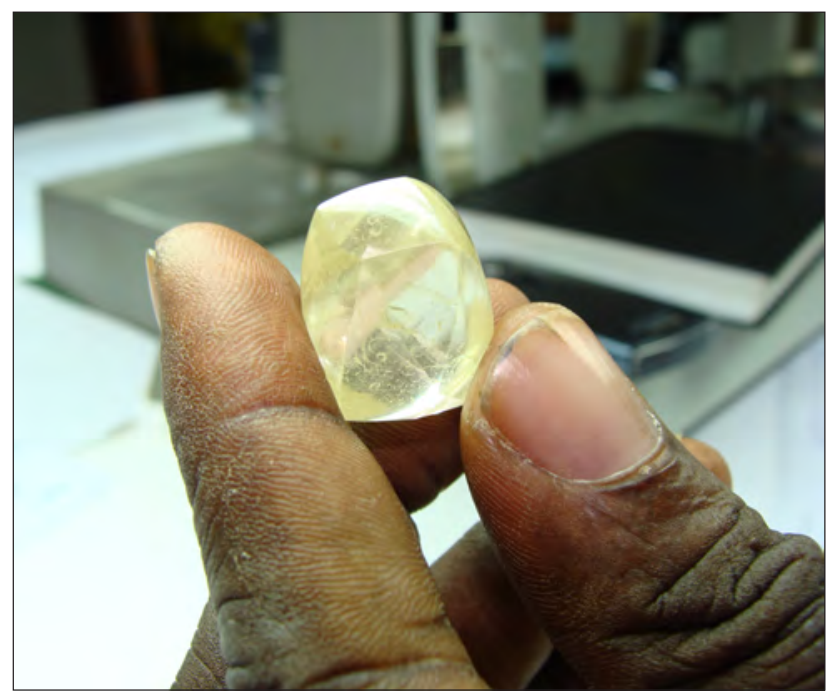

53-carat rough diamond being evaluated at BECDOR in Bangui prior to export, July 2008

are used to develop the cumulative length of streams falling into each of the three categories of stream endowments. The cumulative length of streams within each category was then multiplied by the number of carats per kilometer for that type of stream. The result of the multiplication is a total estimated amount of carats for each stream endowment type for each study area. The total carats per kilometer was summed for each study area, and these values then provided a total estimated endowment for each study area.

Certain areas that fall outside the contoured zones have been included in the content per kilometer assessment approach as complementary areas that interconnect or drain the contoured zones. In particular, rivers and streams of Strahler orders 6, 7, and 8 that connect diamondiferous contour zones or flow from them have been included and treated as separate complementary zones.

\section{Methodology to Estimate the Capacity of the Central African Republic Diamond Production}

Diamond-production capacity is defined as the current volume of diamonds (calculated as total number of carats) that can be produced utilizing current human and physical resources. The estimate of diamond-production capacity does not reflect the possibility of future introduction of new financial capital investment or of improved exploration or mining techniques, nor does it model increases of human resources (labor capital) in the mining sector. Rather, it is a measure of the current state of the diamond mining sector based on recent field data collected and on previous research studies of diamond mining, gravel grades, and estimates of 
the total number of alluvial diamond diggers and small mining cooperatives. To assess the diamond-production capacity, a formulaic model was developed. It can be stated mathematically as

$$
P_{i}=\left(V_{m} / j \times t\right) \times j \times A_{i},
$$

where

$$
\begin{aligned}
& P_{i} \quad \text { is the total current production capacity, } \\
& V_{m} / j \quad \text { is the volume of material worked for each } \\
& \text { digger per day, } \\
& t \text { is the average gravel grade, } \\
& j \quad \text { is the total number of days that a digger works } \\
& \text { per year, and } \\
& A_{i} \quad \text { is the total number of diggers. }
\end{aligned}
$$

\section{Results}

\section{Volume and Grade Results}

Eleven contoured zones of diamond deposits were derived from the point location database showing the location of recorded diamond diggings, workings, and recoveries in the western CAR. For each of the diamondiferous deposit zones, the calculation for volume and grade was performed.

The results of the volume and grade methodological assessment are presented for each diamond deposit zone identified in the mapping. Results are presented separately for the western and eastern zones.

\section{Western Zone}

Table 3 gives the computational results for the western zone. The results table identifies the number of the contour zone and lists the total volume of alluvium for that zone. The total volume of "basic" grade gravels is calculated from the total by dividing it by three-fourths. For the basic gravels of the western CAR, a grade of $0.05 \mathrm{kt} / \mathrm{m}^{3}$ is applied, which then results in the estimated endowment of the basic grade gravels for that zone.

For each contoured zone, the volume of "concentration" grade gravels is calculated as one-fourth of the total alluvium of the zone. The concentration grade (T2) of the western zone gravels is $0.40 \mathrm{kt} / \mathrm{m}^{3}$. The estimated endowment of the concentration grade gravels is calculated by multiplying the concentration volume by the concentration grade, which yields the estimated endowment of concentration grade gravels.

For the western zone, three complementary areas are included in the assessment. These zones represent alluvial diamond deposits lying along rivers and streams corresponding to Strahler order streams 6, 7, and 8.

The total estimated endowments for each zone are then summed. The estimated endowment for "concentration" grade gravel deposits of the western zone is $21,256,539.60$ carats.
When combined with the "basic" grade gravel endowments, the total estimated resource for the western zone is $29,227,741.95$ carats.

\section{Eastern Zone}

Table 4 gives the computational results for the eastern zone. The results table identifies the number of the contour zone and lists the total volume of alluvium for that zone. The total volume of "basic" grade gravels is calculated from the total by dividing it by three-fourths. For the basic gravels of the eastern CAR, a grade of $0.05 \mathrm{kt} / \mathrm{m}^{3}$ is applied, which then results in the estimated endowment of the basic grade gravels for that zone.

For each contoured zone the volume of "concentration" grade gravels is calculated as one-fourth of the total alluvium of the zone. The concentration grade (T2) of eastern zone gravels is $0.30 \mathrm{kt} / \mathrm{m}^{3}$. The estimated endowment of the concentration grade gravels is calculated by multiplying the concentration volume by the concentration grade, which yields the estimated endowment of concentration grade gravels.

The total estimated endowments for each zone are then summed. The estimated endowment for "concentration" grade gravel deposits of the eastern zone is $18,157,072.20$ carats. When combined with the "basic" grade gravel endowments, the total estimated resource is $27,235,608.30$ carats.

\section{Results of the Content per Kilometer Approach}

Tables 5 and 6 give the results of the content per kilometer approach. The total stream lengths are derived from the GIS for the contoured zones known to be diamondiferous. From the total length, percentages are derived according to the classification of the lengths into "very rich," "rich," and "poor" streams. For the western zone 10 percent of the total stream length is classified as very rich, 20 percent is classified as rich, and the remaining 70 percent is classified as poor. Similarly for the eastern zone, 5 percent of the total stream length is classified as very rich, 20 percent is classified as rich, and the remaining 75 percent is classified as poor.

Each classified stream length per zone is multiplied by the estimated content per kilometer and finally summed by zone. In the western zone, very rich deposits are estimated at 7,500 kt/km, rich deposits are estimated at 2,500 kt $/ \mathrm{km}$, and poor deposits are estimated at $850 \mathrm{kt} / \mathrm{km}$. The eastern zone deposits are estimated to be slightly less rich than the western deposits. Therefore, very rich deposits are estimated at $6,000 \mathrm{kt} / \mathrm{km}$, rich deposits are estimated at $1,500 \mathrm{kt} / \mathrm{km}$, and poor deposits are estimated at $500 \mathrm{kt} / \mathrm{km}$.

The total estimated deposits of the western zone, according to the content per kilometer approach, are $37,055,662.90$ carats. The total estimated deposits of the eastern zone, according to the content per kilometer approach, are $26,966,767.01$ carats. 


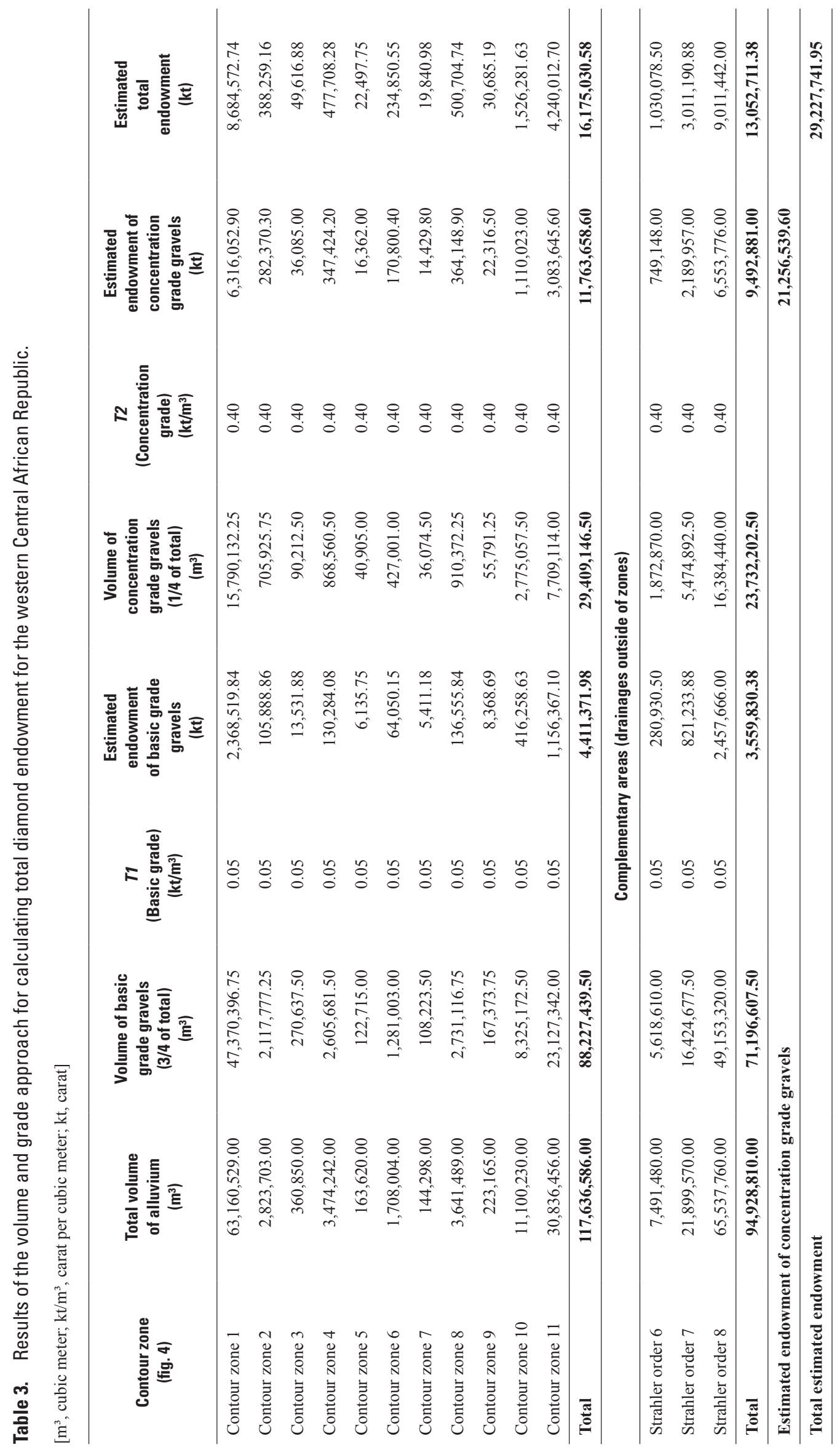




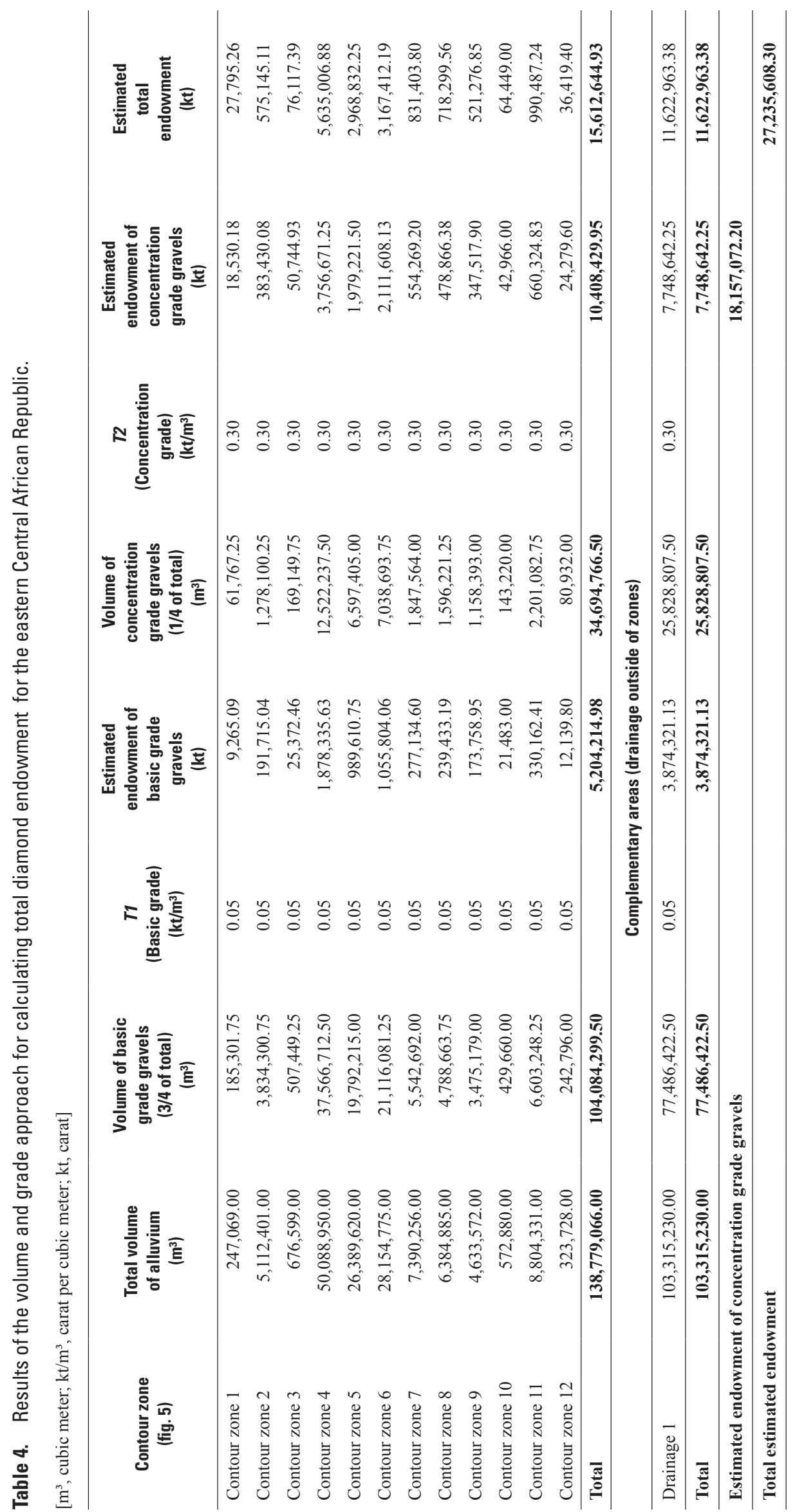


Results 17

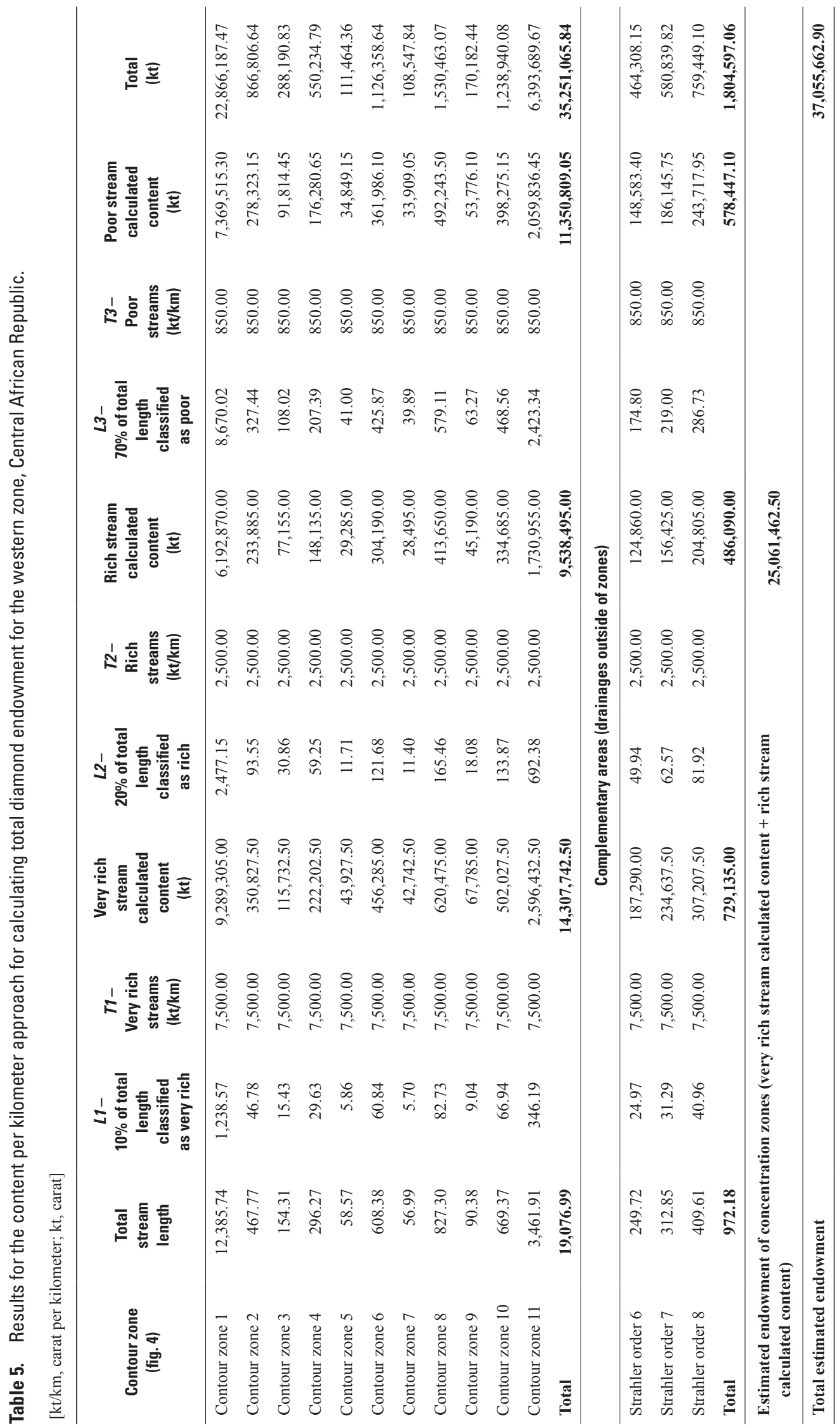




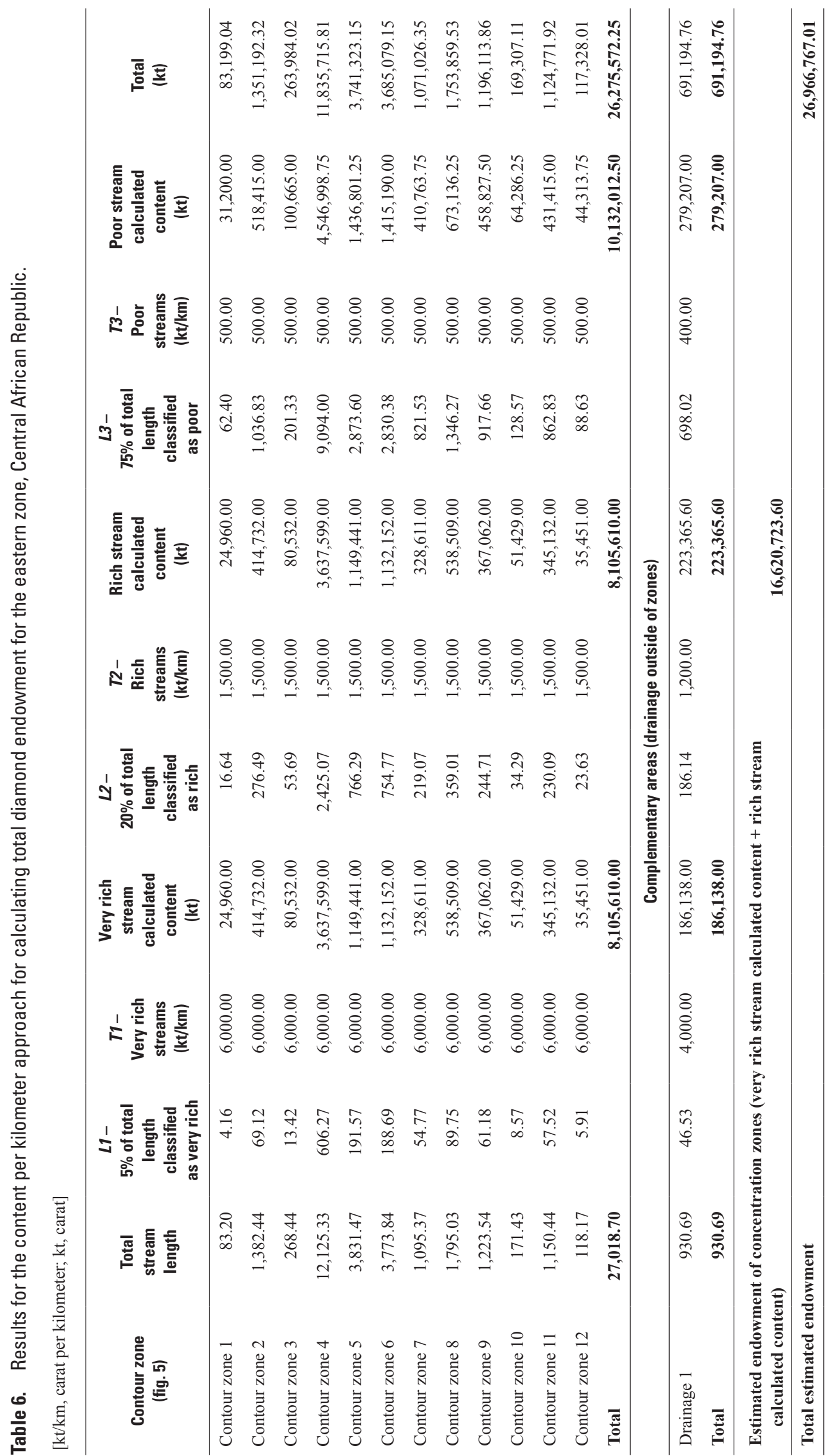


Speculative calculations were performed for the diamond resources of the eastern plateau (table 7). This estimation is a result of the surface-area approach to estimating the diamond resources of the Mouka-Ouadda Plateau. The total surface area of the plateau is derived from the GIS for the current extent of the Cretaceous sandstone of the eastern zone. A "basic" grade of $0.01 \mathrm{kt} / \mathrm{m}^{3}$ is applied to 75 percent of the total surface area, and a "concentration" grade of $0.30 \mathrm{kt} / \mathrm{m}^{3}$ is applied to the remaining 25 percent. Concentration gravels are estimated to be $0.80 \mathrm{~m}$ thick, and basic gravels are estimated at $0.20 \mathrm{~m}$ thick. From these parameters, an inferred total of reserve diamond resources is calculated for the plateau of $3,568,084.74$ carats.

Table 8 gives the results of the estimated diamond resource endowment for the estimated remaining diamonds of both the western and eastern plateaus. This table lists the estimated endowments of both "basic" and "concentration" grades from both methods. Subtracted from these estimated total endowments are the total amounts of diamonds that have been documented to have been exported from the CAR since 1931. The remaining amount is the estimated total endowment of the CAR diamond resources.

The mean total estimated diamond resources remaining in the CAR are calculated to be a total of 39,185,397.98 carats. The total remaining resources within concentration diamond zones are calculated to be $26,482,116.05$ carats. The total remaining resources are calculated to be approximately twice the total historical production of diamonds exported from the CAR since 1931.

\section{Diamond-Production Capacity Results}

The diamond-production capacity model was used to calculate the estimated production capacity of the CAR. Based on observations made in the field during the two field excursions, the following parameters were developed. The grade (g) parameter used for the evaluation is the mean value of the eastern and western zones and is $0.35 \mathrm{kt} / \mathrm{m}^{3}$. Human mining activity $\left(V_{m} / j\right)$ is calculated to be $0.2 \mathrm{~m}^{3}$ per miner per day and takes into account the highly variable situations across the country and also incorporates the overall stripping ratio range of approximately from 0 to 30:1 for the deposits. The total number of days $(j)$ worked is estimated to be 200 days a year and takes into account seasonal variables and inaccessibility of many of the deposits during the rainy season. The total number of diggers estimated during reconnaissance fieldwork $\left(A_{i}\right)$, including artisans and registered workers, is 8,500 , but the total number of artisans and workers is estimated to be 60,000 including hired permanent workers. The total number of diggers ranges from 60,000 to 90,000 . The production potential was calculated using about 60,000 workers based on BRGM documentation of licensed artisanal miners $(\sim 8,500) \times 5-10$ diggers for each team of hired diggers.

Given the parameters above, the calculation of production capacity from equation 4 is given as

$$
840,000=(0.2 \times 0.35) \times 200 \times 60,000 .
$$

The results of this estimated model are higher than the current annual production of approximately 450,000 carats per year. Part of the reason for this result is that many of the diamond areas are not currently mined because of their remote nature, unsecured status, and unproductive workings. Therefore, this estimation should be considered an ideal evaluation that could be attainable given the best possible conditions, not a realistic view that is based on actual conditions.

\section{Conclusions}

The goal of this study was to estimate the alluvialdiamond resource endowment and to estimate the current production capacity of the alluvial-diamond mining sector of the Central African Republic. Two models were used to conduct the alluvial-diamond resource assessment. First, diamond resources were estimated by using a volume and grade approach. Second, the resource was estimated using the content per kilometer approach. The production capacity of the sector was estimated using a formulaic expression of the number of workers reported in the sector, their productivity, and the average grade of deposits mined.

It remains challenging to acquire data at the level of detail required to accurately estimate the parameters for alluvial diamond resources. In this study, calculations were made on the basis of modeling of the parameters of alluvial deposits, grades of deposits, and human resources engaged in the artisanal mining sector. Alluvial flat widths and volume calculations, diamond-deposit grade data, and the number and location of active mining sites are some of the more significant components of this study that could be improved with more detailed data-gathering efforts.

Alluvial flat widths were modeled as a dependent variable to the stream order. While these flat widths were selectively measured in the field, it is understood that there is a great deal more variability in the width of alluvial flats than is modeled using the basic approach of this study. The stream ordering technique itself is also highly dependent on the digital elevation model and derived hydrologic network.

The known grades of alluvial diamond deposits in the CAR have largely been taken from previously published studies and geologic investigations. These studies were conducted only for certain areas and were not conducted recently. Therefore, more information on the grades of deposits throughout the CAR would assist in developing a more detailed analysis of endowment and worker productivity. However, gathering data on the grades of diamond deposits requires extended periods of time in the field to conduct appropriate sampling methodologies.

This study estimates that there are approximately $39,000,000$ carats of alluvial diamonds remaining in both the western and eastern zones of the CAR. This figure is roughly twice the total amount of diamonds reported to have been exported from the CAR since 1931. Production capacity is 

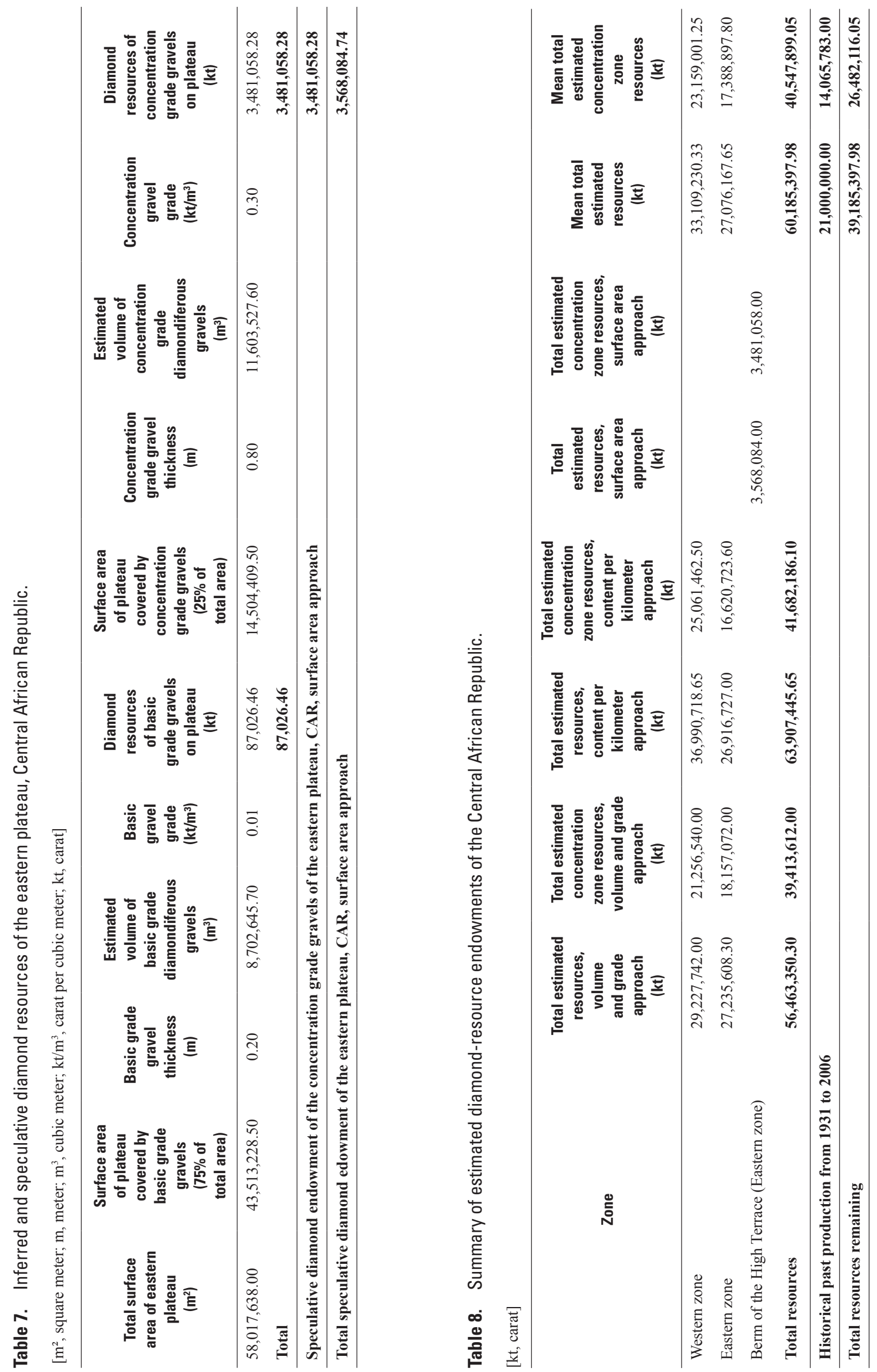
calculated to be 840,000 carats per year, based on the formula and available data on the number of workers and worker productivity. This number is nearly twice the 450,000 carats per year reported annually by the CAR. The difference in these numbers reflects the lack of sufficient data on diamond resource grades, worker productivity, and the number and locations of sites currently being worked. Annual production is highly dependent on national security and stability, the numbers of seasonal workers actively mining in the sector, and environmental conditions that influence seasonal farming.

\section{References Cited}

Bardet, M.G., 1974, Géologie du diamant, gisements de diamants d'Afrique: BRGM Memoir, v. 2, no. 83, 223 p.

Barthélémy, F., and others, 2006, Republic of the Congo, diamond potential, production capacity, and the Kimberley Process-Final report: BRGM, RC-54589-EN, 99 p.

Bates, R.L., and Jackson, J.A., eds., 1984, Dictionary of geological terms ( $3 \mathrm{~d}$ ed.): New York, Random House, American Geological Institute.

Beauvais, A., 1989, Étude pétrographique et géochimique de profils d'altération latéritique cuirassés dans le Sud-Est de la République Centrafricaine: Géodynamique v. 4, no. 2 , p. 71-91.

Beauvais, A., 1999, Geochemical balance of laterization processes and climatic signatures in weathering profiles overlain by ferricretes in Central Africa: Geochimica et Cosmochimica Acta, v. 63, no. 23-24, p. 3939-3957.

Beauvais, A., and Roquin, C., 1996, Petrological differentiation patterns and geomorphic distribution of ferricretes in Central Africa: Geoderma, v. 73, no. 1-2, p. 63-82.

Burton, J.P., and Fralick, P., 2003, Depositional placer accumulations in course grained alluvial braided river systems: Economic Geology, v. 98, p. 985-1001.

Censier, Claude, 1990, Characteristics of Mesozoic fluvial lacustrine formations of the western Central African Republic (Carnot Sandstones) by means of mineralogical and exoscopic analyses of detrital material: Journal of African Earth Sciences, v. 10, no. 1-2, p. 385-398.

Censier, Claude, 1996, Alluvial diamond deposits in the Central African Republic: Africa Geoscience Review, v. 3, no. 2, p. 217-230.

Censier, Claude, and Lang, Jaques, 1992, La formation glaciaire de la Mambéré (République Centrafricaine), Reconstitution paléogéographique et implications à l'échelle du Paléozoïque africain: Geologishe Rundschau, v. 81 , no. 3 , p. $769-789$.
Censier, Claude, and Lang, Jaques, 1999, Sedimentary processes in the Carnot Formation (Central African Republic) related to the paleogeographic framework of Central Africa: Sedimentary Geology, v. 127, no. 1-2, p. 47-64.

Censier, Claude, Lang, Jaques, Mbongo, B.H., and Latou, A., 1992, Mise en évidence d'une formation glaciaire paléozoïque dans l'est de la Republique Centrafricaine, La formation glaciaire de la Kombélé: Paris, Comptes Rendus de l'Académie des Sciences, v. 315, no. 6, p. 711-715.

Censier, Claude, and Tourenq, Josette, 1986, Mise en évidence d'une extension occidentale des grès de Carnot (République Centrafricaine) par analyses sédimentologiques comparées de gisements alluvionnaires diamantifères: Géodynamique, v. 1 , no. 1, p. 21-32.

Dempster, A., and Tutusaus, J.P., 1995, Project d'elaboration d'un plan minier national de la République Centrafrique: Rapport Final - Tome 2, Annexe 9 - Brochure promotionelle sur le sectuer minier centrafricain, Sécretaire d'Etat aux Finaces, au Plan et á la Cooperation Internationale, B.P. 696, Bangui: Ireland, Crowe Schaffalitzky Associates.

Dietrich, Christian, 2003, Diamonds in the Central African Republic, Trading, valuing and laundering, in Smillie, Ian, The Diamonds and Human Security Project: Partnership Africa Canada, Occasional Paper \#8, 8 p.

Erlich, E.I., and Hausel, W.D., 2002, Diamond deposits, Origin, exploration, and history of discovery: Society for Mining, Mettellurgy, and Exploration, Inc., 374 p.

Giresse, Pierre, 2005, Mesozoic - Cenozoic history of the Congo Basin: Journal of African Earth Sciences, v. 43, no. 1-3, p. 301-315.

Hearn, P.P., Jr., Hare, T.M., Schruben, P., Sherrill, D., LaMar, C., and Tsushima, P., 2001, Global GIS, global coverage DVD: American Geological Institute, DVD.

Le Billon, Philippe, 2008, Diamond wars? Conflict diamonds and geographies of resource wars: Annals of the Association of American Geographers, v. 98, no. 2, p. 345-372.

Lescuyer, J.L., and Milési, J.P., 2004, Africa GIS and SIGAfrique network - Geological and metallogenic information system, tools for sustainable development: France, 20ème Colloque de Géologie Africaine.

Malingbar, A., Lang, J., Buoncristiani, J.-F., and Censier, C., 2006, The Mouka-Ouadda Formation, A Cretaceous fluviatile environment in the Eastern part of the Central African Republic: Africa Geoscience Review, v. 13, no. 3-4, p. 301-322.

Olsson, Ola, 2006, Diamonds are a rebel's best friend: The World Economy, Blackwell Publishing, v. 29. no. 8, p. $1133-1150$. 


\section{Alluvial Diamond Resource Potential and Production Capacity Assessment of the Central African Republic}

Petit, M., 1985, A provisional world map of duricrust, in Douglas, I., and Spencer, T., eds., Environmental change and tropical geomorphology: London, George Allen \& Unwin, p. 269-279.

Schlüter Thomas, 2006, Geological atlas of Africa, with notes on stratigraphy, tectonics, economic geology, geohazards and geosites of each country: Berlin, Springer, 272 p.

Strahler, A.N., 1964, Quantitative geomorphology of drainage basins and channel networks, in Chow, V.T., ed., Handbook of applied hydrology: McGraw-Hill, p. 4-40.

Sutherland, D.G., 1985, Geomorphological controls on the distribution of placer deposits: Journal of the Geological Society of London, v. 142, no. 5, p. 727-737.
Tardy, Y., Kobilsek, B., and Paquet, H., 1991, Mineralogical composition and geographical distribution of African and Brazilian periatlantic latertites - The influence of continental drift and paleoclimates during the past 150 million years and implications for India and Australia: Journal of African Earth Sciences, v. 12, no. 1-2, p. 283-295.

Wahl, R.R., 2007, Geologic, geophysical, and mineral localities map of Liberia-A digital compilation: U.S. Geological Survey Open-File Report 2007-1258, 2 DVDs. 


\section{$\frac{\mathbb{R}}{\mathrm{c}}$}

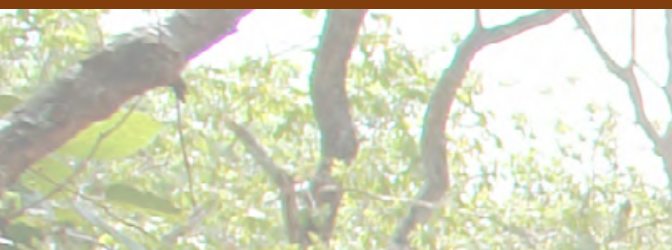

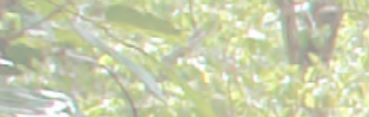

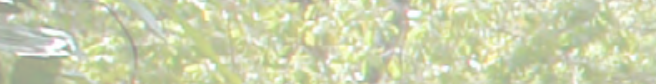

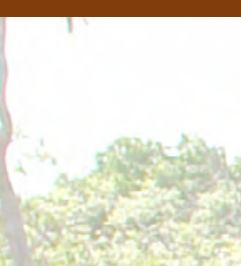

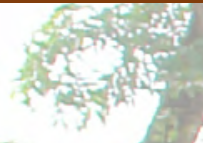

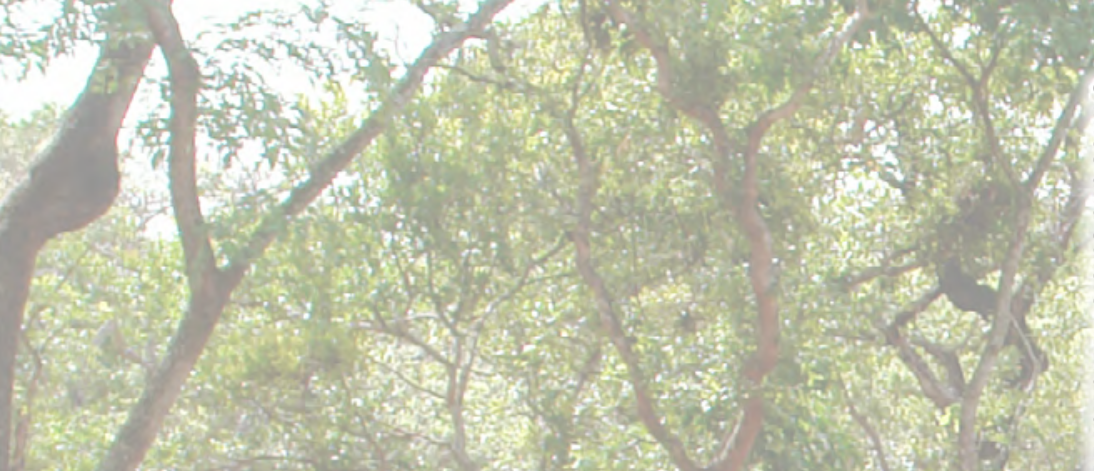

2.

$\frac{1}{2}=5$

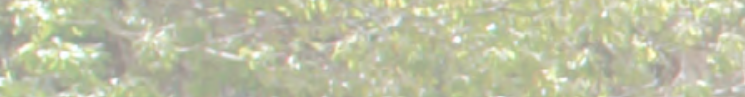

(x)

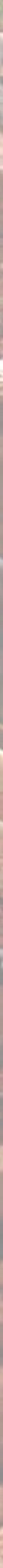

